University of Wollongong

Research Online

Faculty of Business - Papers (Archive)

Faculty of Business and Law

$1-1-2014$

Portfolio quality and mutual fund performance

David R. Gallagher

Macquarie Graduate School of Management

Peter A. Gardner

Plato Investment Management

Camille Schmidt

Macquarie University

Terry S. Walter

University of Sydney, twalter@uow.edu.au

Follow this and additional works at: https://ro.uow.edu.au/buspapers

Part of the Business Commons

Research Online is the open access institutional repository for the University of Wollongong. For further information contact the UOW Library: research-pubs@uow.edu.au 


\title{
Portfolio quality and mutual fund performance
}

\author{
Abstract \\ This study investigates how the quality of stocks owned by mutual funds affects the performance of \\ those funds during 2000-2009. The quality of a stock is positively related to its size, while quality is \\ inversely related to volatility. Evidently, stocks in the lowest quality decile perform particularly poorly \\ amidst volatile market conditions with a mean monthly Daniel, Grinblatt, Titman and Wermers (DGTW) \\ alpha $1.93 \%$ [25.73\% per annum (pa)] less than high-quality stocks. Furthermore, funds which hold the \\ lowest quality stocks exhibit substantial underperformance, particularly during market downturns, with \\ funds in the lowest decile of quality incurring a mean monthly DGTW alpha $0.96 \%(12.14 \% \mathrm{pa})$ lower than \\ their higher quality counterparts. Interestingly, we discover a trend to funds investing in higher quality \\ stocks over time. \\ Disciplines \\ Business \\ Publication Details \\ Gallagher, D. R., Gardner, P. A., Schmidt, C. H. \& Walter, T. S. (2014). Portfolio quality and mutual fund \\ performance. International Review of Finance, 14 (4), 485-521.
}




\title{
Portfolio Quality and Mutual Fund Performance*
}

\author{
David R. Gallagher ${ }^{a}$ Camille H. Schmidt ${ }^{\mathrm{b}, \dagger}$ and Terry S. Walter ${ }^{\mathrm{c}}$ \\ Current Draft: August 2011 \\ ${ }^{a}$ Macquarie Graduate School of Management, North Ryde, N.S.W. 2109 AUSTRALIA and \\ Capital Markets CRC Limited, Sydney 2000 N.S.W. AUSTRALIA \\ ${ }^{b}$ Macquarie Graduate School of Management, North Ryde, N.S.W. 2109 AUSTRALIA and \\ Capital Markets CRC Limited, Sydney 2000 N.S.W. AUSTRALIA \\ and Mercer Investment Consulting, Sydney, N.S.W. AUSTRALIA \\ ${ }^{c}$ School of Finance, University of Technology, Sydney, N.S.W. 2007 AUSTRALIA
}

\begin{abstract}
This study investigates the overall level of "quality" of the stocks held by active mutual funds in the United States, using the portfolio holdings of 2,913 funds in the period 1990-2009. The evidence shows that stocks with the lowest quality perform particularly poorly, with a mean annual DGTW alpha of $-14.57 \%$, significant at the $5 \%$ level, reported for stocks in the lowest decile of quality. Furthermore, there is a direct (inverse) relationship between size (volatility) and quality. Funds which hold the lowest quality stocks exhibit significant underperformance. Evidence of the downside protection offered by quality stocks in volatile market conditions is also examined. Furthermore, lower quality funds have higher portfolio turnover, higher expenses and are slightly younger on average.
\end{abstract}

JEL classification: G11, G23

Keywords: Mutual Funds, Active Management, Investment Performance, Fundamental Analysis; Quality; Stock Holdings

* The authors gratefully acknowledge invaluable comments provided by Stephen Taylor, Yaowen Shan and Nick White and the generous financial support provided by the Capital Markets Co-operative Research Centre and Mercer Investment Consulting.

$\dagger$ Corresponding author. E-mail address: cschmidt@cmcrc.com 


\title{
Portfolio Quality and Mutual Fund Performance
}

\begin{abstract}
This study investigates the overall level of "quality" of the stocks held by active mutual funds in the United States, using the portfolio holdings of 2,913 funds in the period 1990-2009. The evidence shows that stocks with the lowest quality perform particularly poorly, with a mean annual DGTW alpha of $-14.57 \%$, significant at the 5\% level, reported for stocks in the lowest decile of quality. Furthermore, there is a direct (inverse) relationship between size (volatility) and quality. Funds which hold the lowest quality stocks exhibit significant underperformance. Evidence of the downside protection offered by quality stocks in volatile market conditions is also examined. Furthermore, lower quality funds have higher portfolio turnover, higher expenses and are slightly younger on average.
\end{abstract}

JEL classification: G11, G23

Keywords: Mutual Funds, Active Management, Investment Performance, Fundamental Analysis; Quality; Stock Holdings 


\section{Portfolio Quality and Mutual Fund Performance}

\section{Introduction}

Much research has been undertaken in the past two decades examining mutual fund performance, including the components of returns, the characteristics and strategies adopted by mutual fund managers, and attributes of portfolio design. This has been possible with the availability of quarterly portfolio holdings data that enable researchers to better detect the sources of alpha generated by fund managers related to the assets owned by the fund. Given the recent market volatility associated with the Global Financial Crisis (GFC), the market has paid increasing attention to the quality of assets managed by professional investors (Sechler, 2009; McDonald, 2007 and McKay, 2006) and the use of fundamental analysis to assess investments (Sorensen, 2009; Nekrasov and Shroff, 2009 and Beneish et al., 2001) particularly during times of market stress. The flight-to-quality phenomenon has become prevalent recently given the GFC and tight credit markets. When the economy shows signs of weakening, investors may benefit if they focus on larger companies with robust businesses that are more likely to survive the rough times. Furthermore, given illiquidity and expensive credit markets investors become more selective about the stocks that they purchase. Essentially, "by moving your assets toward high-quality, less-risky issues, you can potentially save investment money if the market goes into a downturn" (Tortoriello, cited in McKay, 2006, p. C1). In this study, we extend the mutual fund literature by examining the linkage between the quality of assets that mutual funds include in their portfolios, and the relation of quality to fund performance. Mutual Funds that hold portfolios of stocks which exhibit higher levels of quality are expected to exhibit lower volatility in returns and provide greater downside protection to investors.

This paper contributes to the extant literature by providing an investigation into whether active fund managers hold quality stocks and if so, how these quality dimensions relate to alpha generation. The portfolio holdings characteristic literature has not explicitly examined funds from this perspective (for example, Grinblatt and Titman, 1989; Falkenstein 1996; Chen et al. 2000; Chan et al., 2002; Covrig et al., 2006). In other related studies examining quality and stock attributes, Piotroski (2000) examines portfolio formations using a fundamental analysis strategy targeting value stocks, whereas Mohanram (2005) extends this analysis to growth stocks and Bird and Casavecchia (2007) examine sentiment and financial health indicators for European value and growth stocks. However, the relationship between 
quality stock holdings and performance has not yet been established in the literature. Indeed, the emphasis to date has been on one measure only - the performance impacts of earnings quality. ${ }^{1}$ In the portfolio management industry, professional consulting firms now scrutinise the dimensions of portfolio holdings of fund managers, and report these attributes to trustees of pension funds. These include reporting style attributes and the factor tilts that portfolios have (including measures of quality). The assessment of funds in this manner therefore implies that fund attributes are an important consideration in monitoring.

Our evidence shows that stocks with the lowest quality perform particularly poorly, with a mean annual alpha of $-14.57 \%$, significant at the $5 \%$ level, for stocks in the lowest quality decile. Furthermore, there is a direct (inverse) relationship between size (volatility) and our measure of quality (Q-Score). Interestingly, the overall level of quality attributable to the funds has increased over time, with the mean Q-Score for funds in decile 1 (decile 10) ${ }^{2}$ increasing from -7.11 (4.94) in 1999 to -1.28 (9.54) in $2007 .^{3}$ The funds which hold the lowest quality stocks exhibit significant underperformance. In particular, funds in portfolios one and two have average adjusted returns of $-3.35 \%$ and $-1.39 \%$, which are significant at the $5 \%$ and $10 \%$ levels, respectively. The downside protection offered by quality stocks amidst stressful market conditions is also evident. For example, during the time of the GFC funds in decile 1 incurred a mean return of $-6.33 \%$ compared to $5.51 \%$ for decile 10 . This result is consistent with the flight-to-quality phenomenon previously discussed. Lower quality funds also have higher turnover and expenses and are slightly younger on average.

The remainder of this paper is organised as follows. Section two discusses the relevant extant literature and section three details the data used in the study and summary statistics. Sections four and five describe the research design employed and the empirical results for the Investing Measures and Q-Score analysis, respectively. Finally, section six provides concluding comments.

\section{Background}

\subsection{Quality Measures}

\footnotetext{
${ }^{1}$ Sloan (1996); Dechow and Dichev (2002); Francis et al. (2005); Aboody et al. (2005); Chan, et al. (2006); Ali et al. (2008); Resutek (2010); Wu et al. (2010); Taylor (2010, pers. comm., 10 Mar.).

${ }^{2}$ We rank fund managers' portfolios on the Q-score from lowest to highest quality, and then form deciles.

3 The Q-Score was calculated for 9 years ranging from 1999-2007 and the associated DGTW-alpha was examined over 9 periods from July 2000-June 2009. This is due to the use of the data for the earlier periods as an estimation window for the rolling regressions used to obtain the weights to apply to each metric in order to compute the Q-Score.
} 
The classification of a stock as a 'quality' investment is subjective and various metrics and ratings may be utilised. Investors may undertake fundamental analysis, particularly of accounting records to assess a stock's quality. Badrinath, Gay and Kale (1989) examine the relationship between institutional investment behaviour and quality characteristics of firms based on Standard and Poor's quality rankings. However, recent analysis of stock quality within the mutual fund literature is limited. There are various measures which may be used as indicators of quality such as return on equity, low accruals, and various stability metrics (Mercer Investment Consulting, 2010).

However, academic research has focused on the impact of accruals and specifically the implied level of earnings quality. Sloan (1996) pioneered the accruals anomaly literature by emphasising that high accruals result in lower future returns of $-5.5 \%$ in the following year. Allen, Larson and Sloan (2010) extend Sloan's (1996) analysis of the accruals anomaly by demonstrating that the predictable earnings changes and stock returns following extreme accruals result from the reversal of accrual measurement errors. Chan et al. (2006) and Fama and French (2006) also determine a negative relation between accruals and returns. Recently, analysis of the accruals anomaly has focused on further deconstruction of the components (Zhang, 2007) and the relationship between disclosure quality and mispricing (Drake et al.,, 2009 and Mashruwala and Mashruwala, 2010).

Ali et al. (2008) develop an 'Accruals Investing Measure' in order to quantify whether US mutual funds trade on the accruals anomaly. Mutual fund stockholdings and return data are used to determine which funds pursue an accruals-based trading strategy and whether it is profitable. It is determined that few if any funds trade on the accruals anomaly, although trading on the accruals anomaly is profitable after taking transaction costs into account. Specifically, the top $10 \%$ of funds have the highest weights on low-accruals stocks (although this exposure is not large) and these funds earn a Fama-French 3 -factor alpha of $2.83 \%$ per annum.

Evidently, the concept of stock quality and portfolio holdings has predominantly been examined in a relatively one-dimensional manner to date i.e., earnings quality. ${ }^{4}$ Thus, a detailed analysis of the various indicators of stock quality and determination of aggregate

\footnotetext{
4 Although, Piotroski (2000), Mohanram (2005) and Bird and Casavecchia (2007) examine quality aspects associated with value and growth stocks, the analysis is conducted on a relevant universe of stocks and not applied to the stock holdings of mutual funds.
} 
quality levels (based on quality attributions of stocks held) associated with US equity funds is valuable. Specifically, the methodology employed by Ali et al. (2008) is extended to 14 metrics deemed to be indicative of stock quality.

\subsection{Portfolio Holdings Characteristics}

Prior studies pertaining to the characteristics of fund managers' portfolio holdings are varied in their approach. Grinblatt and Titman (1989) find that 77 percent of the mutual funds analysed were momentum investors and on average, funds that invested on momentum realised significantly better performance than other funds. Falkenstein (1996) determines a preference toward stocks with high visibility and low transaction costs, and an aversion to stocks with low idiosyncratic volatility. Chan et al. (2002) assert that fund managers with poor past period performance, are more likely to alter their investment style towards growth stocks and past period winners.

Covrig et al. (2006) find that managers prefer stocks with high return on equity, large turnover, and low return variability and they also exhibit differential investment behaviour. Domestic managers also favour firms that pay large dividends, have low financial distress and high growth potential, whereas foreign managers prefer to invest in corporations that are globally well known. Cohen et al. (2005) examine portfolio holdings and returns to many funds in order to assess manager skill and the performance of a single fund. It is determined that managers who make similar decisions have similar skill levels. The authors propose that high quality stocks are those that are predominantly held by highly skilled managers.

\subsection{Accounting Measures}

Previous studies emphasise various accounting measures as indicators of firm performance, financial health and operating efficiency. Dichev and Tang (2009) find that the consideration of earnings volatility brings substantial improvements in the prediction of both short- and long- term earnings. Furthermore, Chen and Zhang (2007) determine that profitability (ROE) is an important factor in explaining future stock price movements, more so than scale related factors.

Fairfield and Whisenant (2000) state that fundamental analysis can be used to detect signals of deteriorating firm performance and that these signals contained in public information have not been priced into the market. George and Hwang (2010) examine the relation between stock returns, financial distress and leverage. They find that the average return to high (low) 
debt portfolio is consistently lower (higher) than that of a benchmark neutral portfolio. In addition, Donaldson (1961) emphasises that firms prefer internal sources of funds and favour debt to equity if external financing is required.

Taylor (2010, pers. comm., 10 Mar) conducted research pertaining to how quantitative fund managers assess quality and that indicates that ROE, $\triangle \mathrm{ROE}$ and ROA are commonly used to disaggregate profitability. Stability of profitability is better reflected by asset turnover efficiency as a profit margin can easily be competed away. Academic literature has extensively examined unexpected accruals but it's not really used in practice as it lacks power (Taylor 2010, pers. comm., 10 Mar). Consequently, fund managers prefer to use cash flow vs. accruals comparisons. Nowadays the emphasis has moved back to accounting ratios. Fund managers such as State Street and BlackRock use very common fundamental analysis processes. Smaller funds/boutique funds also exhibit a lot of commonality as they are usually set up by senior people who have left the larger firms.

\section{4 Investment Strategies and Fundamental Analysis}

It has been established that value stocks outperform growth or glamour stocks, although the underlying source of the outperformance is debatable. ${ }^{5}$ Lette (2004) asserts that active managers implementing value strategies incorporate other relevant screens such as fundamental analysis of value stocks prior to portfolio formation. Thus, the abnormal returns attributed to value investing may not be as prominent or tractable as is implied within the academic literature. Interestingly, Desai et al. (2004) determine that the variable operating cash flow scaled by price captures the mispricing attributable to four value-growth proxies and accruals. Furthermore, Beaver (2002 cited in Desai et al., 2004) proposes that the accruals anomaly is the glamour phenomenon in disguise.

Ou and Penman (1989) use financial statement analysis to combine a large set of financial statement items into one summary measure which indicates the direction of one-year-ahead earnings changes. The strategy developed provides returns over a two year holding period of $7 \%$ after adjusting for size and risk factors. Piotroski (2000) states that mean returns to high book-to-market investors can be increased by at least $7.5 \%$ annually by discriminating between ex ante winners and losers. Fundamental analysis is conducted in order to categorise firms as either 'winners' or 'losers'. An F-Score is calculated for firms based on nine

\footnotetext{
${ }^{5}$ Fama and French (1995), Lakonishok et al. (1994), La Porta (1996), La Porta et al. (1997), Cohen et al. (2003), Desai et al. (2004), Chan and Lakonishok (2004) and Campbell and Vuolteenaho (2004).
} 
variables across three categories: profitability (ROA, CFO, $\triangle \mathrm{ROA}$, Accruals); liquidity, leverage and source of funds ( $\Delta$ Leverage, $\Delta$ Liquidity, equity offering) and operating efficiency ( $\Delta$ Margin, $\Delta$ Turnover). The F-Score is the aggregate of a series of binary variables attributed to each variable e.g. if ROA is positive then the firm receives a value of one for this variable.

Mohanram (2005) extends this approach by developing a GSCORE to discriminate between high and low quality growth stocks. A long-short strategy based on this GSCORE earns significant excess returns, though most of the returns come from the short side. A contextual approach towards fundamental analysis is advised, with traditional analysis appropriate for high book-to-market stocks and growth oriented fundamental analysis appropriate for low book-to-market stocks. Furthermore, Bird and Casavecchia (2007) examine both value and growth stocks using 24 fundamental accounting variables across three categories; profitability, financial strength and operating efficiency. Sentiment and financial health indicators are employed to identify growth and value stocks which are more likely to add value over the next 12 months. Over holding periods of up to 12 months, higher added value is possible to be extracted from a 'good' growth portfolio than from a 'good' value portfolio.

Essentially, the approach implemented in these studies of value and growth stocks is extended to examine quality stocks, with the computation of a Q-Score. Thus, the signals incorporated have been selected on the basis of their merits as an indication of quality.

\section{Data}

\subsection{Sample Selection}

The equity holdings of all US mutual funds which existed in any given quarter over the period Jan. 1990-Dec. 2009 were obtained from the Thomson Reuters Mutual Fund Holdings (s12) Database. ${ }^{6}$ The s12 quarterly holdings contained in the N-30D form each fund periodically files with the SEC were extracted via Wharton Research Data Services (WRDS).

The s12 dataset contains holdings data for funds with a variety of investment objectives. The focus of this study is US Active Equity Fund Managers- therefore all international funds

\footnotetext{
${ }^{6}$ Previous studies using mutual fund holdings data often merge the Thomson Reuters Mutual Fund Holdings (s12) database with the CRSP Mutual Fund Database (CMFD) using Mutual Fund Links (MFLINKS). The analysis in this paper focuses primarily on the accounting characteristics of the stocks held, and not the characteristics of the funds- which is what the CMFD is predominantly used for. Therefore, the s12 database was selected in order to maintain the size of the sample. The key results in this paper are presented for the merged sample obtained using MFLINKS, as a robustness check in section 5.5 of this paper.
} 
(Investment Objective Code $(\mathrm{IOC})=1$ ), municipal bonds $(\mathrm{IOC}=5)$, bond and preferred $(\mathrm{IOC}=6)$, balanced ${ }^{7}(\mathrm{IOC}=7)$, metals $(\mathrm{IOC}=8)$ and unclassified funds $(\mathrm{IOC}=9$ ) were removed. Furthermore, funds for which the IOC was reported as missing were removed. These exclusions are consistent with Ali et al. (2008) and Barras et al. (2010) and similar to Wermers (1999; 2000) and Kacperzczyk et al. (2008). Thus, the final sample includes funds with the following investment objectives; 'Aggressive Growth' $(\mathrm{AG} ; \mathrm{IOC}=2)$, 'Growth' $(\mathrm{G}$; $\mathrm{IOC}=3)$ and 'Growth and Income' $(\mathrm{G} \& \mathrm{I}$; IOC $=4) .{ }^{8}$ Ali et al. (2008) state that there are occurrences where funds have been misclassified, thus these funds were manually identified and removed from the sample. ${ }^{9}$ In addition, all funds with portfolio assets less than $\$ 5$ million, and those which held fewer than ten stocks as at the end of the prior quarter were excluded (Kacperzczyk et al., 2008). ${ }^{10}$

The stock level data were obtained from the Centre for Research in Security Prices (CRSP), also via WRDS. The universe of CRSP stocks comprises US common stocks indicated by share codes 10 and 11 and only includes stocks which are traded on the NYSE, AMEX or NASDAQ. The CRSP exchange code (EXCHCD) is used to identify stocks traded on these exchanges instead of the header exchange code (HEXCD) so as to avoid a selection bias in which firms are selected based on their current listing and not their listing as at the point in time being analysed (Kraft et al., 2006).

Moskowitz (2000) purports that it would be fruitful to correct for the delisting bias in the CRSP tapes when examining reported equity holdings. ${ }^{11}$ Therefore, delisting returns from CRSP are used as the stock return for the month in which the firm is delisted when available. Missing performance related (Delisting Codes 500 and 505-588) delisting returns are replaced by $-30 \%$ for NYSE and AMEX stocks and -55\% for NASDAQ stocks (Shumway, 1997 and Shumway and Warther, 1999). ${ }^{12}$ The portfolio holdings observations were merged

\footnotetext{
${ }^{7}$ Balanced funds were removed as this IOC group contains funds which invest in both stocks and bonds. Balanced in this context does not refer to the investment style which is a blend of value and growth strategies.

${ }^{8}$ Grinblatt et al. (1995) provide information about the investment strategies followed, and types of securities invested in, by funds characterised by these investment objectives.

${ }^{9}$ Passive funds $(n=159)$, Foreign-based and US-based international funds $(n=475)$, fixed-income funds $(n=16)$, precious metal funds $(n=8)$, real estate funds $(n=80)$, balanced funds $(n=50)$, variable annuity funds $(n=44)$, convertible funds $(n=40)$ and options funds $(n=9)$ comprise the set of misclassified funds removed over the period 1990-2009.

10 Refer to appendix A for a detailed description of the database construction.

11 The difference between mean gross and DGTW-adjusted fund returns if delisted returns are included vs. Excluded is minute.

${ }^{12}$ The mutual fund returns were also calculated using the approach established by Beaver et al. (2007) to account for missing delisting returns. Specifically, if the delisting return is missing from CRSP then the average
} 
with the monthly CRSP data as per Kacperzczyk et al. (2008) and portfolio returns, stock counts and the value of assets under management were subsequently computed.

\subsection{Summary Statistics}

Table 1 reports summary statistics for the sample of mutual funds at five-year intervals over the period 1990-2009. Panel A details the number of funds in the study across each IOC category and in aggregate. The total number of funds does not represent the total number of unique funds as some funds change the IOC group with which they identify in a given year. 'Growth' funds account for the greatest proportion of funds throughout the sample period. Furthermore, the number of 'Growth' funds increased by $100 \%$ over the sample period, despite falling from a peak of 1,255 in 1999. Interestingly, the amount of 'Aggressive Growth' funds decreased, by approximately $18 \%$ over the sample period.

\section{[INSERT TABLE 1]}

Panel B reports the proportion of funds reporting as per the calendar period. These proportions are based on the complete dataset prior to the number of stocks and value of assets exclusions. Overall, the majority of funds report as per the calendar period, thus it is appropriate to classify funds into quarters based on the month of the report date, which is consistent with Wermers (2000).

Panel $\mathrm{C}$ reports the average (median) number of different stocks held by each fund, per quarter, over the year. The average number of stocks held per fund increased between 19902009 across all funds, and within each IOC group. Specifically, the average number of stocks held by all mutual funds was 62 at the end of 1990, increasing to 111 by the end of 2009 . Interestingly, growth funds held the greatest number of stocks on average at each time period snapshot. In addition, statistics not presented in Table 1 (in the interests of brevity) show that the dispersion within each category and across all funds is quite high in each period and it has increased with time as the number of stocks held has increased. In particular, the standard deviation was 60 stocks in 1990, increasing to 139 stocks by the end of 2009.

Panel D shows the average (median) dollar value of assets (in millions) held by each fund, per quarter, based on the reported equity holdings. The average value of assets under

delisting return for all stocks with the same 3-digit delisting code is used as a proxy. There was no difference in the average fund returns reported in Table 2 when this method was used. 
management has increased considerably over the sample period growing from \$205 million per quarter in 1990 to $\$ 1,110$ million in 2009 , despite falling slightly from 2004 to 2009 . The most substantial increases in fund size are visible over the period 1994 to 1999, which is not surprising given the technology boom that occurred during this period. In particular, the percentage change in fund size was $198 \%$ for all funds, and $296 \%, 181 \%$ and $194 \%$ for AG, G and G\&I funds, respectively.

Panels E, F and G report the average (median) asset-weighted size, book-to-market and momentum quintiles, respectively, to which the stocks were assigned based on the Daniel et al. (DGTW) (1997) and Wermers (2003) approach. The value-weighted average characteristic quintile is first calculated for each fund, based on the holding value of each stock, at the end of the prior quarter. The average (median) is then calculated across the funds in each quarter. Size, book-to-market and momentum portfolios 1 consist of small, low bookto-market and low prior-year return stocks, respectively.

Panel E indicates that US mutual funds hold stocks which are large, with funds holding stocks which, on average, fall above the fourth size quintile for NYSE stocks. Furthermore, at each time-interval snapshot the same pattern is evident with G\&I funds holding the largest stocks, followed by G, and then AG funds. Panel F shows that the book-to-market ratio of stocks held by mutual funds is around the median of that for stocks listed on the NYSE. Furthermore, G\&I funds prefer stocks with higher book-to-market ratios relative to $G$ and AG funds, respectively. Panel G demonstrates that AG funds prefer stocks which have exhibited higher price momentum relative to G and G\&I funds, respectively. On average, mutual funds prefer stocks with momentum slightly higher than that exhibited by NYSE stocks. Specifically, the mean oscillates around the third quintile across all periods. Overall, the investment style exhibited across fund categories over time is relatively similar; this is consistent with DGTW (1997).

\section{[INSERT TABLE 2]}

Table 2 presents average performance measures for the sample of US mutual funds covered by the s12 database, over the period 1990-2009. All funds that existed during a given quarter are included, irrespective of whether or not they were subsequently active. Thus, the sample is free from survivorship-bias. 
The total number of distinct funds studied over 1990-2009 is 2,913, which is comparable with previous studies. ${ }^{13}$ The total number of funds covered increased by $72 \%$ over the sample period, growing from 646 in 1990 to 1,113 in 2009. This was predominantly fuelled by 'growth' funds which rose in number by 100\% from 1990-2009 (see Table 1). However, since a peak of 2,026 funds in 1998 the total number of funds has gradually decreased.

The return on the CRSP value-weighted index (including dividends) is presented to facilitate comparison between the mutual funds' performance and the market. The annualised returns on the CRSP value-weighted index including dividends are obtained through compounding of the component monthly returns.

The individual fund returns are calculated as the weighted-average of the returns to the stocks contained in the portfolio. The holding value of a stock as at the end of the prior quarter is the weight applied to that stock's return over the next quarter, which is consistent with Wermers (2000). Moskowitz (2000) confirms that this is to avoid the impact of end of quarter window dressing by fund managers. These weights are normalised across each fund snapshot. The mean gross returns for the sample of funds are calculated by first determining the mean return for each quarter using all funds that existed during that quarter. The quarterly returns are then annualised using simple compounding- both asset-weighted (AW) and equally-weighted (EW) results are presented. The asset weights are based on the reported assets held by the fund as at the end of the prior quarter and these weights are normalised across each quarter. The individual gross and adjusted stock returns and the gross and adjusted fund returns were winsorised at the top and bottom $1 \%$ in order to avoid the impact of extreme observations. ${ }^{14}$

Over the entire sample period US mutual funds underperformed the market by ten basis points on an AW basis before costs. However, the EW gross returns indicate that funds outperformed the index by 65 basis points. Although, this evidence appears mixed once fees and transaction costs are considered, on average US mutual funds underperform the market, which is consistent with previous research. ${ }^{15}$

\footnotetext{
13 Ding and Wermers (2005) analyse 2,689 funds over 1985-2002; Ali et al. (2008) and Kacperzczyk et al. (2008) examine 2,587 and 2,786 funds, respectively over the period 1984-2003; Massa and Patgiri (2009) examine 3,095 funds between 1996-2003 and Barras et al. (2010) study 2,076 funds over 1975-2006.

${ }^{14}$ The results presented in Table 2 are qualitatively the same when the individual stock returns and the fund returns are trimmed at the top and bottom $1 \%$.

${ }^{15}$ Gruber (1996) determines that mutual funds underperform an appropriately weighted average of indices by about 65 basis points per year. Carhart (1997) finds that most funds underperform by about the magnitude of their investment expenses. Wermers (2000) purports that after taking fees and expenses into account mutual funds underperform the market.
} 
The gross fund returns are adjusted using the DGTW (1997) and Wermers (2003) characteristic benchmark approach. ${ }^{16}$ The DGTW-adjusted returns are provided on an AW and EW basis. These returns are calculated by subtracting the buy-and-hold return on a valueweighted portfolio of stocks from each stock held by a fund in a given quarter. The stocks are assigned to one of 125 benchmark portfolios in June of each year on the basis of the interaction of its size, book-to-market and momentum characteristics. ${ }^{17}$ The 5 -year average AW (EW) mean DGTW-adjusted fund returns are all negative except for the period 19901994 for which a small positive return of 47 (49) basis points is reported. Furthermore, over the complete sample period mutual funds underperform their characteristic matched counterparts by 48 (34) basis points per annum on an AW (EW) basis.

\section{Investing Measures Research Design and Results}

Table 3 details the 14 quality signals which were selected for analysis subsequent to a review of the academic literature. The metric values for each stock were adjusted by the relevant population median, from the prior fiscal year. The metric values were not industry-adjusted in order to allow for the impact of industry bets executed by the fund managers. ${ }^{18}$ The metric values were also winsorised at the $1^{\text {st }}$ and $99^{\text {th }}$ percentiles to avoid the impact of extreme observations.

\section{[INSERT TABLE 3]}

\subsection{Research Design}

Ali et al. (2008) compute an 'Accruals Investing Measure'. This approach is extended by applying it to the 14 accounting metrics detailed in Table 3 . The same research method is used for each metric thus; ROE will be used as an example.

Firstly, all stocks in the Compustat database with the data required to compute ROE for the fiscal year that ends in calendar year $t-1$ are identified. CRSP and DGTW data must be obtainable for the stocks in order to assess the relationship between ROE and stock returns. Additionally, stocks must be classified as common equity (CRSP share codes 10 or 11) and

\footnotetext{
${ }^{16}$ The DGTW benchmarks are available via http://www.smith.umd.edu/faculty/rwermers/ftpsite/Dgtw/coverpage.htm

17 This is consistent with previous studies e.g. Ding and Wermers (2005); Alexander et al. (2007) and Kacperczyk et al. (2008).

${ }^{18}$ The results for the Investing Measures are qualitatively similar for the 14 metrics if the values of each metric for each stock are scaled by the median for each stock's 2-digit SIC group for the prior fiscal year.
} 
traded on the NYSE, AMEX or NASDAQ (CRSP exchange codes 1, 2 and 3). Furthermore, stocks with SIC codes between 6000-6999 (financials) were removed. ${ }^{19}$ In each year $t$, all sample stocks in the CRSP/Compustat/DGTW universe are sorted into equally-weighted decile portfolios based on their ROE for the fiscal year that ends in the calendar year $t-1$. Decile 1 represents the stocks with the lowest ROE values.

The Investing Measure (IM) is defined as the weighted average decile rank of the individual stocks. The Compustat/CRSP/DGTW universe consists of all stocks with the data required to compute ROE. In this case the weight applied to each stock's decile rank is its market capitalisation as at December of year $t-1$ as a proportion of the total market capitalisation of all stocks in the ROE universe. The analysis is repeated on a subsample of stocks which are held by at least one mutual fund as at June of each year $t$. In this case a double-weighting approach is applied to the decile rank of each stock.

Specifically, the double-weighting approach involves initially calculating each stock's share of the market relative to the universe of stocks for which ROE data is available, as at the end of June of each year $t$ (MC-Weight).

$$
\text { MC-Weight }=\frac{\text { Market } \text { Capitalisation i,t }}{\sum_{i=1}^{N} \text { Market } \text { Capitalisationi, } t}
$$

Where;

- Market Capitalisation of stock $i$, at the end of June of year $t=\mathrm{PRC}^{*}$ Shares

- $\quad$ PRC $=$ unadjusted price of stock $i$ at the end of June of year $t$ from CRSP

- $\quad$ Shares $=$ unadjusted number of shares outstanding for stock $i$ at the end of June of year $t$ from CRSP

- $\quad N=$ the number of stocks in the ROE universe in June of year $t$

Subsequently, the total holding value of each stock, per mutual fund in June of each year is calculated (MF-Weight).

$$
\text { MF-Weight }=\quad \frac{H V A L U E i, t}{\sum_{i=1}^{N} H V A L U E i, j, t}
$$

Where;

\footnotetext{
${ }^{19}$ This is due to the fact that financial firms do not have the data required to compute the accruals metric and their removal is consistent with prior accruals literature (Allen et al., 2010). Furthermore, the results for the other metrics are not qualitatively altered upon their inclusion and the sample sizes do not increase dramatically.
} 
- $\quad$ The holding value (HVALUE) of stock $i$, at the end of June of year $t=\mathrm{P} *$ Adj-Shares

- $\quad \mathrm{P}=$ adjusted price of stock $i$ at the end of June of year $t$ from CRSP

- Adj-Shares = adjusted shares held as per the June report date of year $t$ from the s12 holdings data.

- $\quad N=$ the number of stocks in the ROE universe held by fund $j$ in June of year $t$.

It is then possible to calculate the positions each mutual fund is taking in each stock as follows:

\section{Mutual Fund Position (Position) $i, j, t=$ MF-Weight $i, j, t-$ MC-Weight $i, t$}

Where;

- Position indicates whether fund $j$ is overweight/underweight stock $i$ in June of year $t$.

- If the fund is overweight (underweight) stock $i$, the position will be positive (negative).

The stocks are then sorted into equally-weighted deciles based on the value of ROE for the fiscal year ending in year $t-1$. The sum of the positions in stock $i$ taken by all of the funds which held stock $i$ in June of year $t$ is calculated. The position in stock $i$ taken by each fund $j$ is weighted by the size of the fund, in June of year $t$.

Where;

$$
\text { SumPosition } i, t=\sum_{j=1}^{K} \text { Positioni }, j, t * W j, t
$$

- $\quad K=$ the number of funds which held stock $i$ in June of year $t$

- $\mathrm{Wj}, t=\underline{\text { Assetsj,t}}$

Total Assets $t$

Where Assets $j, t=\sum_{i=1}^{N} H V A L U E i, j, t$ where $N=$ the number of stocks held by fund $j$ in June of year $t$ and Total Assets $=\sum_{j=1}^{K}$ Assetsj, $t$.

Subsequently, the total weight to be applied to each stock per decile is able to be computed as follows;

$$
\text { Total Weight }=\text { SumPosition } i, t+\text { MC-Weight } \text {. }
$$

A low (high) IM for the universe indicates that larger stocks have lower (higher) values of ROE. Furthermore, if the difference between the IM for the universe and the stocks held by mutual funds is positive (negative) this indicates that mutual funds tilt their equity holdings towards stocks with higher (lower) values of ROE, relative to the universe. A mutual fund IM 
which is not significantly different from the universe IM indicates that the metric is not a key variable considered when constructing portfolios.

\subsection{Results}

Table 4 presents mean values of the IMs for each quality signal over the sample period.

\section{[INSERT TABLE 4]}

\section{Profitability Signals}

The ROE, ROA, $\triangle$ ROA and OCF IMs for the universe are above average and significantly higher than the IMs for the mutual fund stocks. The difference between the mutual fund and the universe IMs is about -0.4 for each of these metrics, which is significant at the $0.1 \%$ level. Therefore, mutual funds tend to tilt their portfolios toward stocks with slightly lower values of these metrics, on average, relative to the universe. However, relative to an expected value of 5.50 mutual funds tend to hold larger stocks with higher ROE generally, which is consistent with Covrig et al. (2006). This may be due to the varying investment styles exhibited by mutual funds (i.e., value managers target "cheap" stocks which tend to have low levels of ROE).

The universe and mutual fund IMs for $\triangle \mathrm{ROE}$ are slightly above the expected value of 5.50. Although the difference is statistically significant it's minute and mutual funds do not exhibit a strong positive tilt based on this metric. Overall, the results support Taylor's (2010, pers. comm., 10 Mar) statement that fund managers assess profitability using ROE, $\triangle \mathrm{ROE}$ and ROA.

The ACC IM for the universe is not statistically different from the expected value; however it is at the $10 \%$ level for the mutual fund stocks. This indicates a slight preference to lower ACC stocks by mutual funds, which suggests that mutual funds as a whole do trade on the accruals anomaly, although not aggressively. In contrast, Ali et al. (2008) determine that mutual funds as a whole do not trade on the accrual anomaly with an IM of 5.55 reported which is not statistically different from 5.50.

\section{Variability Signals}

The variability metrics exhibit a similar pattern; the universe IMs show that larger stocks have lower ROA VAR and SG VAR, as they are significantly lower than the expected value. 
Evidently, mutual funds tend to tilt toward stocks with higher variability than the universe, with statistically significant differences of 0.47 and 0.42 reported for ROA VAR and SG VAR, respectively.

\section{Operating Efficiency Signals}

The universe IM for ATO is significantly lower than the expected value however; the mutual fund IM is not, whilst the difference between the two IMs is minute yet highly statistically significant. Whereas, neither the universe IM nor the mutual fund IM are significantly different from the expected value for $\triangle \mathrm{ATO}$. Overall, operating efficiency ratios individually do not appear to be key metrics considered when forming portfolios.

\section{Financial Health Signals}

The IMs for leverage are both moderately higher than the expected value and significant at the $0.1 \%$ level; however they are only slightly different from each other, although this difference is statistically significantly. Whereas, the universe IM for liquidity indicates that larger stocks have much lower working capital-to-assets ratios and this is similar to mutual fund stocks, albeit slightly higher. The universe IM for $\Delta \mathrm{SH}$ is statistically different from the expected value; however the mutual fund IM is not. The IMs for $\Delta \mathrm{TE}$ are significantly different, however not substantially, and not on an individual level.

Therefore, the strongest relationships exhibited across the metrics are predominantly by the profitability and variability signals - ROA, $\triangle$ ROA, OCF and ROA VAR. ROE, ROA and $\triangle \mathrm{ROA}$ are clearly positive signals and ROA VAR and $\triangle \mathrm{SH}$ are negative signals. The evidence so far indicates that despite the negative impact of a $\Delta \mathrm{SH}$ mutual funds do not consider this factor to be important when constructing their portfolios.

\section{Quality Score Research Design and Results}

\subsection{Research Design}

Piotroski (2000) constructs a binary F-Score in order to differentiate value firms on the basis of quality. Therefore, each signal is examined under the condition that the firms are financially distressed at some level. Piotroski (2000, p. 7) states that "to the extent the implications of these signals about future performance are not uniform across the set of high book-to-market firms, the power of the aggregate score to differentiate between strong and weak firms will ultimately be reduced". 
Given that the firms examined in this study are not differentiated on the basis of financial health or similar, they are a sample of firms with all of the required data to compute each metric included in the Q-Score. Therefore, it is fruitful to extend Piotroski's (2000) binary approach in order to incorporate the ambiguous relationships between alpha and some of the metrics. In order to incorporate the relative importance of each metric and allow for more complex relationships which may be inherent, univariate regressions were performed. Specifically, regressions were performed to investigate the relationship between each metric and alpha, as per the following model:

$$
y=\beta_{0}+\beta_{1} x+\beta_{2} x^{2}+\varepsilon
$$

Where;

- $\quad y$ represents DGTW alpha- the dependent variable

- $\quad \beta_{0}$ represents the intercept

- $\quad \beta_{1}$ represents the parameter estimate for the metric in question- $x$ - an independent variable

- $\quad \beta_{2}$ represents the coefficient estimate for the squared value of the metric in question- $x^{2}-$ an independent variable

- $\varepsilon$ represents the error term

The DGTW alpha for each stock in the Compustat/CRSP/DGTW universe was regressed on the metric value for the stock as well as the metric value squared in order to capture any nonlinear relationships. The parameter estimates are interpreted as follows; for each 1 unit increase in ROE (ROE squared), for example, DGTW alpha changes by $\beta_{1}\left(\beta_{2}\right.$ ) percent.

These regressions were run over rolling time periods - the first regression was run using the estimation period 1989-1998, the parameter estimates obtained were then used to calculate each metric's contribution to the Q-Score using the metric values for 1999. The Q-Score for 1999 was then merged with the mutual fund holdings as at June of 2000, and alpha was examined from July 2000-June 2001. Essentially, this allows the predictive capability of the Q-Score constructed to be examined without the impact of any hindsight biases. The second regression was run using data from 1989-1999, the third from 1989-2000 and so on up to an estimation period of 1989-2006. Thus, the parameter estimates for each of the nine regressions were used on the associated metric values for the following year. Overall, the QScore was calculated for nine years ranging from 1999-2007 and the associated DGTW alpha was examined over nine periods from July 2000-June 2009. 
It is hypothesised that;

- H1: Stocks of low quality as indicated by the Q-Score will exhibit poor DGTW-adjusted performance, on average.

- H2: During stressful market periods stocks of lower quality as indicated by the Q-Score will exhibit lower levels of DGTW-adjusted performance, on average, relative to stocks of higher quality.

- H3: Funds which hold greater proportions of low quality stocks will exhibit poor DGTWadjusted performance, on average.

- H4: During stressful market periods funds which hold stocks of lower quality as indicated by the Q-Score will exhibit lower levels of DGTW-adjusted performance on average, relative to funds which hold stocks of higher quality.

\subsection{Univariate Results}

The average parameter estimates obtained for each metric from the nine regressions are reported in Table $4 .^{20}$ These estimates provide information about the magnitude and direction of the relationship between alpha and each metric. The profitability metrics OCF, ROA and $\triangle \mathrm{ROA}$ have the largest positive $\beta_{1}$ parameter estimates- 37.0, 21.3 and 20.2, respectively. The importance of OCF as a determinant of mispricing and thus stock returns is emphasised by this result, which is consistent with Desai et al. (2004). ROE and $\triangle$ ROE have a less substantial impact on alpha with $\beta_{1}$ values of 8.8 and 1.1, respectively. ACC has an inverse relationship with alpha indicated by the negative $\beta_{1}$ estimate of -10.7 .

The large negative $\beta_{2}$ estimate for ACC of -115 indicates that an inverted U-shaped relationship exists between alpha and ACC, which is comparable with the findings of Kraft et al. (2006). Similarly, a slight hump shape characterises the distribution of alpha for $\Delta \mathrm{ROE}$ with a $\beta_{2}$ estimate of -11.5 determined.

The univariate analyses indicate a much stronger relationship between ROA VAR and alpha compared to SG VAR - $\beta_{1}$ is $-50.8(-1.5)$ for ROA VAR (SG VAR). Similar to Dichev and Tang (2009) the predictive capabilities of earnings volatility are highlighted. Furthermore, $\beta_{2}$ for ROA VAR (SG VAR) is moderate (non-existent) at 29.3 (0). Interestingly, the strongest inverted U-shaped relationship is between $\triangle \mathrm{ATO}$ and alpha with a $\beta_{2}$ estimate of -295.4.

\footnotetext{
${ }^{20}$ Refer to Appendix B for a detailed summary of the coefficient estimates for each metric.
} 
The parameter estimates for LEV and $\triangle \mathrm{TE}$ are minute thus these metrics individually do not have a strong relationship with alpha. LIQ has a slight positive impact on alpha with a statistically significant $\beta_{1}$ estimate of 6.2 , in conjunction with a slight hump shaped relationship given the $\beta_{2}$ estimate of $-25.7 . \Delta \mathrm{SH}$ has a negative impact on alpha with a $\beta_{1}$ estimate of -7.5, which is consistent with Donaldson (1961).

\subsection{Q-Score Summary Statistics}

Table 5 presents the average returns and stock characteristics for the deciles formed based on the Q-Score. Section A provides the means for the Compustat/CRSP/DGTW universe of stocks. These are computed by weighting the value of the Q-Score, for each stock, by its market capitalisation as at December of year $t-1$ as a proportion of the contemporaneous total market capitalisation of all stocks in the universe. The analysis is repeated using the aforementioned double-weighting approach in order to account for both a stock's share of the market and the level of exposure that mutual funds have to that stock. ${ }^{21}$ Section B presents the results for this analysis.

In Table 5 no. of stocks is the average number of stocks contained in each decile portfolio over the sample period. Size is the mean market capitalisation of each stock in the portfolio, as at December of year $t-1$. Q-Score value is the mean value of the Q-Score per decile portfolio over the sample period. The raw return is the average unadjusted buy-and-hold return from July of year $t$ to June of year $t+1$ to the stocks in the portfolio. The annual returns are calculated by compounding the monthly CRSP returns for each stock. Annual raw returns greater than $200 \%$ were removed (Kraft et al., 2006). Furthermore, if a stock is delisted within the return accumulation period then the subsequent missing monthly returns are replaced with the return on the appropriate DGTW benchmark portfolio.

The DGTW alpha is the mean excess annual value-weighted return to the stocks in each portfolio over the sample period whereby each stock's raw return is adjusted by the return on an appropriate DGTW benchmark portfolio. The $t$-statistics are in parentheses below the average returns reported. Raw return volatility is the mean annualised standard deviation of

\footnotetext{
${ }^{21}$ The analysis was also conducted on the subset of stocks held by mutual funds as per Ali et al. (2008); however the results were essentially the same given that such a large portion of the stocks in the universe are held by mutual funds. Therefore, the double-weighting approach was used in order to more clearly identify the relationship between the positions that mutual funds take in stocks and the corresponding average returns and characteristics of the stocks.
} 
the unadjusted monthly returns from July of year $t$ to June of year $t+1$ for each stock in the portfolio. Idiosyncratic return volatility is the average annualised standard deviation of the DGTW-adjusted monthly returns from July of year $t$ to June of year $t+1$ for each stock in the portfolio. DGTW benchmark volatility is the mean annualised volatility of the monthly returns from July of year $t$ to June of year $t+1$ for each stock's DGTW benchmark portfolio.

\section{[INSERT TABLE 5]}

Table 5 indicates that stocks with the lowest Q-Scores perform particularly poorly, with a mean DGTW alpha of $-14.57 \%$, significant at the $5 \%$ level, determined for decile 1 . This is consistent with Hypothesis 1. Conversely, a positive DGTW-adjusted return of $4.11 \%$ is determined for decile 8 , which is significant at the $10 \%$ level. In general, there is a direct (inverse) relationship between size (volatility) and the Q-Score. The Q-Scores range on average from approximately -50 for decile 1 to 15 for decile ten, which emphasises the downside risk of lower quality stocks. The results for the mutual fund holdings analysis exhibit similar patterns, although the stocks held by funds are larger on average.

\subsection{Q-Score Results for the Mutual Fund Sample}

Table 6 presents the mean returns to deciles containing mutual funds which have been sorted based on the weighted-average Q-Score for their portfolios. Firstly, in June of each year $t$ the Q-Score for each stock is computed and then the weighted-average Q-Score is computed for each fund based on the holding value of each stock as at June of year $t$. The funds are then ranked into deciles based on their average Q-Score. The mean returns per decile are computed in a similar fashion to the stock returns in Table 5 i.e., the Q-Score sorted deciles are formed in June of each year $t$ and then the returns are calculated from July of year $t$ to June of year $t+1$. All funds with holdings data available in a given quarter of each portfolio formation year are included in the calculation of the mean annual return for that portfolio formation year. Therefore, the results are free from survivorship bias as the mean return is calculated on a quarterly basis and then the annual mean is the compound of these four mean returns.

\section{[INSERT TABLE 6]}

The average Q-Score for decile 1 is -3.8 , which indicates that mutual funds tend to avoid the substantially low quality stocks as the average Q-Score for decile 1 is about -50 for the 
universe. The mean raw fund returns are all relatively similar and statistically insignificant. As per Hypothesis 3, the funds which hold low quality stocks exhibit significant underperformance. In particular, portfolios in deciles 1 and 2 have DGTW-adjusted returns of $-3.35 \%$ and $-1.39 \%$, respectively, which are significant at the 5\% and $10 \%$ levels, respectively.

The mean size, book-to-market and momentum quintiles to which the stocks were assigned based on the DGTW approach are also provided. Firstly, the asset-weighted mean quintile per quarter, each year, across the deciles is calculated. Then the mean of the four quarterly values is calculated each year. The mean quintiles reported below are the time-series means over the sample period. Finally, the proportions of funds which are members of each of the three Investment Objective Code groups included in the study are provided.

The DGTW quintile means vary based on size with the larger stocks populating the higher QScore deciles. However, book-to-market ratio and momentum do not vary substantially across the Q-Score sorted deciles. This is likely to be due to the fact that the grouping of all funds into one aggregate group masks the differences in style characteristics (Ainsworth et al., 2008). The majority of funds are classified as 'Growth' funds across all deciles, with the higher Q-Score sorted deciles containing an increasing (decreasing) proportion of 'Growth and Income' ('Aggressive Growth') funds. This is consistent with the notion that funds which have a higher Q-Score are a more stable investment.

\section{Performance over Time}

Table 7 provides the mean DGTW-adjusted fund returns per decile in each year over the sample period. The year indicates the Portfolio Formation Year (PFY) e.g. 1990 comprises the four quarters commencing from July 1990 to June 1991. The annual return reported is the compound of the four mean quarterly returns for the year. Therefore, every fund which existed in each quarter is included and so the mean annual return is free from survivorship bias. The mean Q-Score for each decile is provided in italics below the mean return. The $t$ statistics are in parentheses below the time-series average of the yearly returns. Volatility is the standard deviation of the mean annual returns over the sample period.

[INSERT TABLE 7] 
The downside protection offered by quality stocks amidst stressful market conditions is evident. For example, during the time of the GFC funds in decile 1 incurred a mean return of $-6.33 \%$ compared to $5.51 \%$ for decile 10 . In order to test this further, the mean of the annual returns for deciles 1 and 10 in PFYs 2000, 2001, 2007 and 2008 were compared. Specifically, a paired sample $t$-test of the difference in the means for these years, deemed to be stressful market periods ${ }^{22}$, revealed that stocks in decile 1 incur a mean return $7.4 \%$ lower than stocks in decile 10 and this difference is significant at the 5\% level. Furthermore, this is the greatest difference exhibited between any of the deciles over these years. This result is consistent with the flight-to-quality phenomenon previously discussed and in support of Hypothesis 4.

Interestingly, the overall level of quality attributable to the funds has increased over time with the mean Q-Score for decile 1 (10) increasing from -7.11 (4.94) in 1999 to -1.28 (9.54) in 2007. On average, volatility doesn't differ substantially across the deciles although it is slightly elevated for decile 1.

Chart 1 depicts the mean DGTW-adjusted returns in each portfolio formation year over the sample period for the top two and bottom two deciles. The returns for the top two deciles are quite stable particularly in comparison to the lowest Q-Score decile funds which exhibit the greatest volatility of returns. The greatest disparity between the top two and bottom two portfolios is evident during times of market stress, with deciles 1 and 2 performing particularly poorly during the dot-com crash and the GFC.

\footnotetext{
${ }^{22}$ The periods were deemed to be stressful based on market events and the National Bureau of Economic Research's (NBER) 'US Business Cycle Expansions and Contractions' reference dates (NBER, 2010). Specifically, PFYs 2000 and 2001 each overlap with the contraction which occurred from March 2001November 2001. Furthermore, PFY 2000 is affected by flow-on effects from the dot-com crash which occurred in March 2000 (Hon et al., 2007). Similarly, PFYs 2007 and 2008 coincide with the contraction that occurred over December 2007-June 2009, which is related to the Global Financial Crisis.
} 


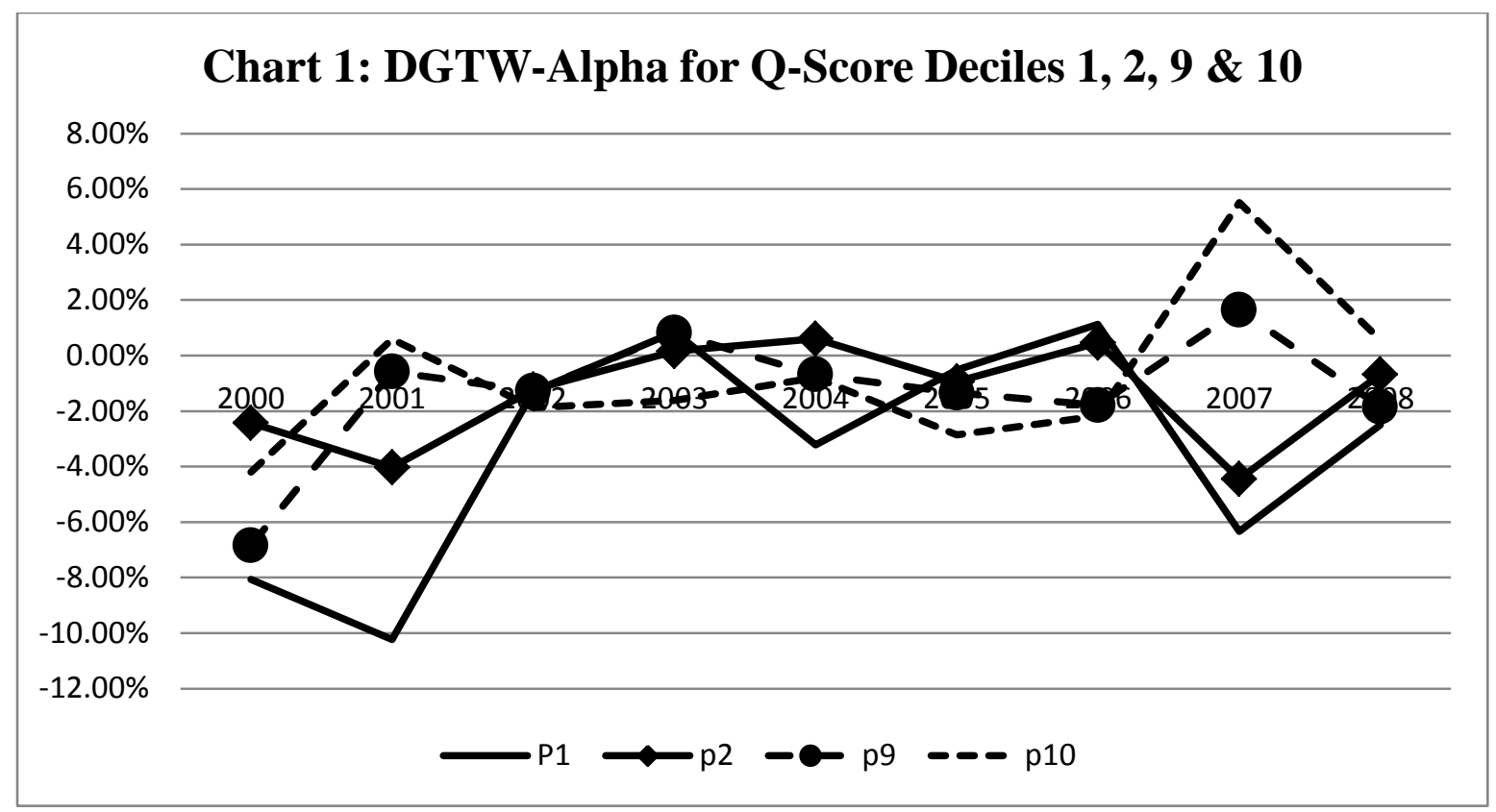

\subsection{Q-Score Results for the Merged Subset}

The Q-Score analysis was repeated on the subset of funds in both the s12 database and the CRSP Mutual Fund database (CMFD) which were able to be linked via Mutual Fund Links (MFLINKS). This was undertaken as a robustness check and in order to gain insight into the characteristics of the funds contained in the sample across the Q-Score sorted deciles. These results are provided in Table 8 and overall they are consistent with those reported for the s12 database sample.

Funds holding low quality stocks exhibit particularly poor performance, with DGTWadjusted returns of $-2.35 \%$ and $-2.39 \%$, for deciles 1 and 2 , significant at the $10 \%$ and $5 \%$ levels, respectively. The mean Q-Score, Book-to-Market, Size and Momentum quintiles and IOC breakdown also exhibit comparable magnitudes and patterns. Furthermore, in unreported results, the performance of the funds in the Q-Score sorted deciles over time is qualitatively similar.

\section{[INSERT TABLE 8]}

The mean values of various fund characteristics sourced from the CMFD are provided, as at June of year $t$. Turnover Ratio is the minimum (of aggregated sales or aggregated purchases of securities), divided by the average 12-month Total Net Assets of the fund. Interestingly, funds in the lowest (highest) quality deciles have the highest (lowest) turnover ratios - the average turnover ratio is $122 \%$ for decile 1 compared to $53 \%$ for decile 10 . 
Fees represents the Management Fee (\$) divided by Average Net Assets (\$). There is no substantial difference in fees across the Q-Score sorted deciles. The Expense Ratio is the ratio of the total investment that shareholders pay for the fund's operating expenses. Funds in the lowest Q-Score deciles are characterised by higher Expense Ratios - specifically, the mean Expense Ratio for decile 1 (decile 10) is 1.86 (1.23).

Age is the number of years since the fund was first offered. Lower quality funds are slightly younger than higher quality funds, on average. Finally, Total Net Assets is as of month-end i.e., June of year $t$, yet this does not appear to be a distinguishing factor across the Q-Score deciles.

\section{Conclusion}

This paper examines the portfolio holdings of U.S. mutual funds in order to gain insight into the relationship between quality stock holdings and performance generation. Substantial underperformance is evident for both stocks and funds which are characterised by the lowest levels of quality. Furthermore, the performance of low and high quality funds diverges substantially during times of market volatility. There are significant losses which may be incurred on the downside, however the relationship is asymmetric, as a strong positive relationship with alpha for high quality stocks is not evident. Our study therefore supports the assertion that quality assets in a portfolio are important, particularly in volatile periods. 


\section{References}

Aboody, D. Hughes, J. and Liu, J. 2005 "Earnings Quality, Insider Trading and Cost of Capital", Journal of Accounting Research, Vol. 43, No. 5, pp. 651-673.

Ainsworth, A., Fong, K. and Gallagher, D. 2008 "Style Drift and Portfolio Management for Active Australian Equity Funds", Australian Journal of Management, Vol. 32, No.3, pp. 387418.

Alexander, G., Cici, G. and Gibson, S. 2007 "Does Motivation Matter when Assessing Trade Performance? An Analysis of Mutual Funds", Review of Financial Studies, Vol. 20, Issue 1, pp. 125-150.

Ali, A., Chen, X., Yao, T. and Yu, T. 2008 "Do Mutual Funds Profit from the Accruals Anomaly?", Journal of Accounting Research, Vol. 46, Issue 1, pp. 1-26.

Allen, E., Larson, C. and Sloan, R. 2010 “Accruals Reversals, Earnings and Stock Returns", University of Western Australia Research Forum, Perth, W.A.

Altman, E. 1968 "Financial Ratios, Discriminant Analysis and the Prediction of Corporate Bankruptcy", The Journal of Finance, Vol. 23, No. 4, pp. 589-609.

Badrinath, S. Gay, G. and Kale, J. 1989, "Patterns of Institutional Investment, Prudence, and the Managerial 'Safety Net' Hypothesis," The Journal of Risk and Insurance, Vol. 56, No. 4, pp. 605-629.

Barras, L., Scaillet, O. and Wermers, R. 2010 "False Discoveries in Mutual Fund Performance: Measuring Luck in Estimated Alphas", The Journal of Finance, Vol. 65, No. 1, pp. 179-216.

Beaver, W., McNichols, M. and Price, R. 2007 "Delisting Returns and their effect on Accounting-Based Market Anomalies", Journal of Accounting and Economics, Vol. 43, pp. 341-368.

Beneish, M., Lee, C. and Tarpley, R. 2001 "Contextual Fundamental Analysis through the Prediction of Extreme Returns", Review of Accounting Studies, Vol. 6, pp. 165-189.

Bird, R. and Casavecchia, L. 2007 "Sentiment and Financial Health Indicators for Value and Growth Stocks: The European Experience", The European Journal of Finance, Vol. 13, No. 8, pp. 769-793.

Campbell, J. and Vuolteenaho, T. 2004 "Bad Beta, Good Beta", American Economic Review, Vol. 94, No. 5, pp. 1249-1275.

Carhart, M. 1997 "On Persistence in Mutual Fund Performance”, The Journal of Finance, Vol. 52, Issue 1, pp. 57-82.

Chan, K., Chan, L., Jegadeesh, N. and Lakonishok, J. 2006 "Earnings Quality and Stock Returns”, Journal of Business, Vol. 79, No. 3, pp. 1041-1082.

Chan, L., Chen, H., and Lakonishok, J. 2002, “On Mutual Fund Investment Styles", Review of Financial Studies, Vol. 15, Issue 5, pp. 1407-1437. 
Chan, L. and Lakonishok, J. 2004, "Value and Growth Investing: Review and Update", Financial Analysts Journal, Vol. 60, Issue 1, pp. 71-86.

Chen, H., Jegadeesh, N. and Wermers, R. 2000, "The Value of Active Mutual Fund Management: An Examination of the Stockholdings and Trades of Fund Managers", Journal of Financial and Quantitative Analysis, Vol. 35, No. 3, pp. 343-368.

Chen, P. and Zhang, G. 2007 "How do Accounting Variables explain Stock Price Movements? Theory and Evidence", Journal of Accounting and Economics, Vol. 43, Issue 2/3, pp. 219244.

Cohen, R., Coval, J. and Pastor, L. 2005 "Judging Fund Managers by the Company they Keep", The Journal of Finance, Vol. 60, Issue 3, pp.1057-1096.

Cohen, R., Polk, C. and Vuolteenaho, T. 2003 "The Value Spread", The Journal of Finance, Vol. 58, Issue 2, pp. 609-642.

Covrig, V. Lau, S. T. and Ng, L. 2006 "Do Domestic and Foreign Fund Managers have Similar Preferences for Stock Characteristics? A Cross Country Analysis", Journal of International Business Studies, Vol. 37, No. 3, pp. 407-429.

Daniel, K., Grinblatt, M., Titman, S. and Wermers, R. 1997 "Measuring Mutual Fund Performance with Characteristic-Based Benchmarks", The Journal of Finance, Vol. 52, Issue 3, pp. 1035-1058.

Dechow, P. and Dichev, I. 2002 "The Quality of Accruals and Earnings: The Role of Accrual Estimation Errors", The Accounting Review, Vol. 77, pp. 35-59.

Desai, H., Rajgopal, S. and Venkatachalam, M. 2004 "Value-Glamour and Accruals Mispricing: One Anomaly or Two?", The Accounting Review, Vol. 79, No. 2, pp. 355-385.

Dichev, I. and Tang, V. 2009 "Earnings Volatility and Earnings Predictability", Journal of Accounting and Economics, Vol. 47, Issue 1/2, pp. 160-181.

Ding, B. and Wermers, R. 2005 "Mutual Fund Performance and Governance Structure: The Role of Portfolio Managers and Boards of Directors", EFA 2005 Moscow Meetings Paper, available at SSRN: http://ssrn.com/abstract=683721

Donaldson, G. 1961 “Corporate Debt Capacity”, Harvard University Press, Cambridge, MA.

Drake, M., Myers, J. and Myers, L. 2009 "Disclosure Quality and the Mispricing of Accruals and Cash Flow", Journal of Accounting, Auditing and Finance, Vol. 24, pp. 357-384.

Fairfield, P. and Whisenant, S. 2000, Using Fundamental Analysis to Assess Earnings Quality: Evidence from the Center for Financial Research and Analysis", Journal of Accounting, Auditing and Finance, Vol. 16, Issue 4, pp. 273-295.

Falkenstein, E. 1996, "Preferences for Stock Characteristics as Revealed By Mutual Fund Portfolio Holdings", The Journal of Finance, Vol. 51, Issue 1, pp. 111-135.

Fama, E. and French, K. 1995 "Size and Book-to-Market Factors in Earnings and Returns", The Journal of Finance, Vol. 50, No. 1, pp. 131-155. 
Fama, E. and French, K. 2006 "Profitability, Investment and Average Returns", Journal of Financial Economics, Vol. 82, Issue 3, pp. 491-518.

Francis, J., La Fond, R., Olsson, P. and Schipper, K. 2005 "The Market Pricing of Accruals Quality", Journal of Accounting and Economics, Vol. 39, pp. 295-327.

George, T., and Hwang, C. 2010 "A Resolution of the Distress Risk and Leverage Puzzles in the Cross-Section of Stock Returns”, Journal of Financial Economics, Vol. 96, pp. 56-79.

Grinblatt, M. and Titman, S. 1989 "Mutual Fund Performance: an Analysis of Quarterly Portfolio Holdings", Journal of Business, Vol. 62, No. 3, pp. 393-416.

Grinblatt, M., Titman, S. and Wermers, R. 1995 "Momentum Investment Strategies, Portfolio Performance, and Herding: A Study of Mutual Fund Behavior", American Economic Review, Vol. 85 Issue 5, pp. 1088-1105.

Gruber, M. 1996 “Another Puzzle: The Growth in Actively Managed Mutual Funds", The Journal of Finance, Vol. 51 Issue 3, pp.783-810.

Hon, M., Strauss, J. and Yong, S. 2007 "Deconstructing the Nasdaq Bubble: A Look at Contagion across International Stock Markets”, Journal of International Financial Markets, Institutions and Money, Vol. 17, Issue 3, pp. 213-230.

Hribar, P. and Collins, D. 2002 "Errors in Estimating Accruals: Implications for Empirical Research”, Journal of Accounting Research, Vol. 40, Issue 1, pp. 105-134.

Kacperzczyk, M., Sialm, C. and Zheng, L. 2008 "Unobserved Actions of Mutual Funds", Review of Financial Studies, Vol. 21, Issue 6, pp. 2379-2416.

Kraft, A., Leone, A. and Wasley, C. 2006 "An Analysis of the Theories and Explanations Offered for the Mispricing of Accruals and Accrual Components", Journal of Accounting Research, Vol. 44, Issue 2, pp. 297-339.

Lakonishok, J., Shleifer, A. and Vishny, R. 1994 "Contrarian Investment, Extrapolation and Risk”, The Journal of Finance, Vol. 49, No. 5, pp. 1541-1578.

La Porta, R. 1996 "Expectations and the Cross-Section of Stock Returns", The Journal of Finance, Vol. 51, No. 5, pp. 1715-1742.

La Porta, R., Lakonishok, J., Shleifer, A. and Vishny, R. 1997 "Good News for Value Stocks: Further Evidence on Market Efficiency", The Journal of Finance, Vol. 52, No. 2, pp. 859874.

Lette, G. 2004 "Value, Growth and Investing", Mercer Investment Consulting, Internal Research Paper, Sydney, Australia.

Lui, D., Markov, S. and Tamayo, A. 2007 "What Makes a Stock Risky? Evidence from SellSide Analysts' Risk Assessments", Journal of Accounting Research, Vol. 45, Issue 3, pp. 629-665. 
Mashruwala, C. and Mashruwala, S. 2010 "The Pricing of Accruals Quality: January vs. the Rest of the Year", Working Paper, Available at SSRN: http://ssrn.com/abstract=1421284

Massa, M. and Patgiri, R. 2009 "Incentives and Mutual Fund Performance: Higher Performance or Just Higher Risk Taking?”, Review of Financial Studies, Vol. 22, Issue 5, pp. 1777-1815.

McDonald, I. 2007 “Investing in Funds: A Quarterly Analysis; Fund Fiend: Homeowners' Woes could Lift Blue Chips in Flight to Quality" Wall Street Journal, New York, Jul. 3, p. R.1.

McKay, P. 2006 "Investors Pay More Attention to Profit Purity", Wall Street Journal, New York, Jun. 26, p. C.1.

Mercer Investment Consulting, 2010, Style Research Analysis, Database, Sydney, Australia.

Modigliani, F. and Miller, M. 1958 "The Cost of Capital, Corporation Finance and the Theory of Investment”, American Economic Review, Vol. 48, Issue 3, pp. 261-298.

Mohanram, P. 2005 "Separating Winners from Losers among Low Book-to-Market Stocks using Financial Statement Analysis", Review of Accounting Studies, Vol. 10, pp. 133-170.

Moskowitz, T. 2000 “Discussion”, The Journal of Finance, Vol. 55, Issue 4, pp. 1695-1703.

Myers, S. and Majluf, N. 1984 "Corporate Financing and Investment Decisions when Firms have Information that Investors do not have", Journal of Financial Economics, Vol. 13, Issue 2, pp. 187-221.

National Bureau of Economic Research, Inc., 2010 "US Business Cycle Expansions and Contractions", Public Information Office, Cambridge, Massachusetts, USA, Available: http://www.nber.org/cycles.html

Nekrasov, A. and Shroff, P. 2009 "Fundamentals-Based Risk Measurement in Valuation", The Accounting Review, Vol. 84, No. 6, pp. 1983-2011.

Ou, J. and Penman, S. 1989 "Financial Statement Analysis and the Prediction of Stock Returns", Journal of Accounting and Economics, Vol. 11, Issue 4, pp. 295-329.

Piotroski, J. 2000 "Value Investing: The use of Historical Financial Statement Information to Separate Winners from Losers", Journal of Accounting Research, Vol. 38, pp. 1-41.

Resutek, R. 2010 "Intangible Returns, Accruals, and Return Reversal: A Multi-Period Examination of the Accrual Anomaly", The Accounting Review, Vol. 85, Issue 4, pp. 13471374.

Sechler, B. 2009 “Jensen Sees Quality Among Battle-Tested”, Wall Street Journal, New York, May 11, p. C.6.

Shumway, T. 1997 "The Delisting Bias in CRSP Data”, The Journal of Finance, Vol. 52, No. 1, pp. 327-340.

Shumway, T. and Warther, V. 1999 "The Delisting Bias in CRSP's Nasdaq Data and its Implications for the Size Effect”, The Journal of Finance, Vol. 54, Issue 6, pp. 2361-2379. 
Sloan, R. 1996 "Do Stock Prices Fully Reflect Information in Cash Flows and Accruals about Future Earnings?” The Accounting Review, Vol. 71, Issue 3, pp. 289-315.

Sorensen, E. 2009 "Active Equity Management for the Future", Journal of Portfolio Management, Vol. 36, Issue 1, pp. 60-68.

Wermers, R. 1999 "Mutual Fund Herding and the Impact on Stock Prices", The Journal of Finance, Vol. 54, Issue 2, pp. 581-622.

Wermers, R. 2000 "Mutual Fund Performance: An Empirical Decomposition into Stock-Picking Talent, Style, Transactions Costs and Expenses", The Journal of Finance, Vol. 55, Issue 4, pp. 1655-1695.

Wermers, R. 2003 "Is Money Really "Smart"? New Evidence on the Relation between Mutual Fund Flows, Manager Behaviour, and Performance Persistence", Working Paper, Available at SSRN: http://ssrn.com/abstract=414420

Wu, J., Zhang, L. and Zhang, X. 2010 "The q-Theory Approach to Understanding the Accrual Anomaly", Journal of Accounting Research, Vol. 48, No. 1, pp. 177-223.

Zhang, G. 2000 "Accounting Information, Capital Investment Decisions, and Equity Valuation: Theory and Empirical Implications", Journal of Accounting Research, Vol. 38, No. 2, pp. 271-295.

Zhang, F. 2007 "Accruals, Investment, and the Accrual Anomaly" Yale School of Management Working Paper, Available at SSRN: http://ssrn.com/abstract=878376 
Table 1: Summary Statistics for Mutual Fund Sample

Key statistics are provided below for the Thomson Reuters Institutional Holdings (s12) Database sample. The statistics are reported at five-year intervals, as at the end of the year, over the period 1990-2009. The s12 Database is survivorship-bias free and provides periodic portfolio holdings of U.S. equities for all mutual funds from 1980 onwards. Panel A indicates the number of funds included in the study across each IOC category and in total. The total number of funds does not represent the total number of unique funds as some funds change the IOC group with which they identify in a given year. Panel B reports the proportion of funds reporting as per the calendar period. These proportions are based on the complete dataset prior to the number of stocks, and value of assets, exclusions. Panel C reports the average (median) number of different stocks held by each fund, per quarter. Panel D provides the average (median) dollar value of assets (millions) held by each fund, per quarter, based on the reported equity holdings. Panels E, F and G report the asset-weighted average (median) size, book-to-market and momentum quintiles, respectively, to which the stocks were assigned based on the DGTW approach. The value-weighted average characteristic quintile is first calculated for each fund, based on the holding value of each stock, at the end of the prior quarter. The average (median) is then calculated across the funds in each quarter. Size, book-to-market and momentum portfolios 1 consist of small, low book-to-market and low prior-year return stocks, respectively.

\begin{tabular}{|c|c|c|c|c|c|}
\hline & \multicolumn{5}{|c|}{ Year } \\
\hline & 1990 & 1994 & 1999 & 2004 & 2009 \\
\hline \multicolumn{6}{|c|}{ Panel A: Number of Funds } \\
\hline Aggressive Growth & 148 & 214 & 170 & 152 & 121 \\
\hline Growth & 376 & 921 & 1,255 & 990 & 752 \\
\hline Growth \& Income & 163 & 281 & 405 & 299 & 240 \\
\hline All & 687 & 1,416 & 1,830 & 1,441 & 1,113 \\
\hline \multicolumn{6}{|c|}{ Panel B: Proportion of Funds Reporting as per the Calendar Period (\%) } \\
\hline Aggressive Growth & 85.52 & 71.18 & 76.89 & 51.89 & 60.27 \\
\hline Growth & 91.86 & 77.31 & 82.52 & 71.98 & 66.29 \\
\hline Growth \& Income & 88.61 & 74.82 & 86.90 & 79.67 & 74.42 \\
\hline All & 89.70 & 76.03 & 82.90 & 71.38 & 67.35 \\
\hline \multicolumn{6}{|c|}{ Panel C: Average (Median) Number of Stocks held per Fund } \\
\hline Aggressive Growth & $61.37(47)$ & $69.51(50)$ & $83.06(59)$ & $98.21(71)$ & $101.19(63)$ \\
\hline Growth & $64.88(45)$ & $84.47(54)$ & $85.35(56)$ & $103.85(67)$ & $112.72(66)$ \\
\hline Growth \& Income & $54.52(43)$ & $65.11(52)$ & $82.42(61)$ & $98.55(67)$ & $110.56(65)$ \\
\hline All & $61.68(45)$ & $78.17(53)$ & $84.48(57)$ & $102.18(67)$ & $110.96(66)$ \\
\hline \multicolumn{6}{|c|}{ Panel D: Average (Median) Assets under Management (\$ million) } \\
\hline Aggressive Growth & $114(50)$ & $261(126)$ & $1034(273)$ & $1235(323)$ & $867(301)$ \\
\hline Growth & $188(64)$ & $224(68)$ & $628(131)$ & $924(233)$ & 919 (227) \\
\hline Growth \& Income & $318(85)$ & $432(88)$ & $1268(225)$ & $1783(350)$ & $1832(411)$ \\
\hline All & $205(65)$ & $272(81)$ & $809(160)$ & $1134(265)$ & $1110(256)$ \\
\hline \multicolumn{6}{|c|}{ Panel E: Average (Median) Size Quintile } \\
\hline Aggressive Growth & $3.57(3.76)$ & $3.61(3.65)$ & $4.33(4.56)$ & $4.19(4.61)$ & $4.13(4.46)$ \\
\hline Growth & $4.31(4.44)$ & $4.23(4.40)$ & $4.60(4.87)$ & $4.38(4.79)$ & $4.43(4.78)$ \\
\hline Growth \& Income & $4.64(4.75)$ & $4.65(4.74)$ & $4.85(4.93)$ & $4.83(4.89)$ & $4.82(4.89)$ \\
\hline All & $4.36(4.57)$ & $4.30(4.53)$ & $4.66(4.88)$ & $4.52(4.84)$ & $4.56(4.83)$ \\
\hline \multicolumn{6}{|c|}{ Panel F: Average (Median) Book-to-Market Quintile } \\
\hline Aggressive Growth & $2.30(2.24)$ & $2.19(2.12)$ & $2.36(2.33)$ & $2.26(2.17)$ & $2.58(2.50)$ \\
\hline Growth & $2.76(2.81)$ & $2.72(2.70)$ & $2.50(2.47)$ & $2.51(2.50)$ & $2.68(2.67)$ \\
\hline Growth \& Income & $3.31(3.23)$ & $3.28(3.26)$ & $2.92(2.92)$ & $2.92(2.93)$ & $2.98(2.88)$ \\
\hline All & $2.93(2.95)$ & $2.86(2.90)$ & $2.64(2.61)$ & $2.63(2.59)$ & $2.79(2.78)$ \\
\hline \multicolumn{6}{|c|}{ Panel G: Average (Median) Momentum Quintile } \\
\hline Aggressive Growth & $3.87(3.86)$ & $3.81(3.82)$ & $4.00(3.94)$ & $3.29(3.29)$ & $3.26(3.31)$ \\
\hline Growth & $3.40(3.35)$ & $3.39(3.38)$ & $3.65(3.70)$ & $3.01(2.96)$ & $3.11(3.07)$ \\
\hline Growth \& Income & $2.96(2.96)$ & $2.95(3.00)$ & $3.13(3.09)$ & $2.64(2.64)$ & $3.02(3.06)$ \\
\hline All & $3.28(3.22)$ & $3.28(3.20)$ & $3.49(3.48)$ & $2.90(2.85)$ & $3.09(3.08)$ \\
\hline
\end{tabular}


Table 2: Mutual Fund Returns

This table presents average performance measures for a sample of U.S. mutual funds covered by the Thomson Reuters Institutional Holdings (13F) database, over the period 1990-2009. The analysis is limited to funds with a self-stated investment objective of either 'aggressive growth', 'growth' or 'growth and income' as at the end of the prior quarter. The annualised returns on the CRSP value-weighted index including dividends are obtained using simple compounding of the component monthly returns. The number of funds is measured as the total number of unique funds that were analysed over the year. The individual fund returns are calculated as the weighted-average of the returns to the stocks contained in the fund's portfolio. The holding value of a stock as at the end of the prior quarter is the weight applied to that stock's return over the next quarter. These weights are normalised across each fund snapshot. The mean gross returns for the sample of funds are calculated by first determining the mean return for each quarter using all funds that existed during that quarter. The quarterly returns are then annualised using simple compounding- both asset-weighted (AW) and equally-weighted (EW) results are presented. The asset weights are based on the reported assets held by the fund as at the end of the prior quarter and these weights are normalised across each quarter. The DGTW adjusted returns are also provided on an AW and EW basis. These returns are calculated by subtracting the buy-and-hold return on a valueweighted portfolio of stocks from each stock held by a fund in a given quarter. The stocks are assigned to one of 125 benchmark portfolios in June of each year on the basis of the interaction of its size, book-to-market and momentum

\begin{tabular}{ccccccc}
\hline Year & $\begin{array}{c}\text { CRSP VW Return } \\
\text { incl. Dividends } \\
\text { (\%/year) }\end{array}$ & $\begin{array}{c}\text { No. } \\
\text { Unique } \\
\text { Funds }\end{array}$ & $\begin{array}{c}\text { AW-Mean } \\
\text { Gross Returns } \\
\text { (\%/year) }\end{array}$ & $\begin{array}{c}\text { EW-Mean } \\
\text { Gross Return } \\
\text { (\%/year) }\end{array}$ & $\begin{array}{c}\text { AW-Mean } \\
\text { DGTW Adj. } \\
\text { Returns }(\% / \text { year) }\end{array}$ & $\begin{array}{c}\text { EW-Mean } \\
\text { DGTW Adj. }\end{array}$ \\
\hline 1990 & -6.08 & 646 & -6.97 & -5.61 & -0.13 & 0.71 \\
1991 & 33.64 & 749 & 37.32 & 40.15 & 0.18 & 1.03 \\
1992 & 9.07 & 865 & 11.38 & 11.51 & 0.33 & -0.22 \\
1993 & 11.58 & 1142 & 14.35 & 13.77 & 2.64 & 1.17 \\
1994 & -0.76 & 1388 & -0.57 & -0.67 & -0.64 & -0.23 \\
1995 & 35.67 & 1603 & 34.86 & 33.80 & 0.55 & -0.26 \\
1996 & 21.16 & 1686 & 20.56 & 21.09 & -1.60 & -0.64 \\
1997 & 30.33 & 1916 & 32.46 & 30.93 & -1.08 & -1.00 \\
1998 & 22.28 & 2027 & 18.63 & 13.67 & -0.54 & -0.35 \\
1999 & 25.27 & 1830 & 17.85 & 18.31 & -1.43 & -2.58 \\
2000 & -11.08 & 1728 & -1.40 & 2.85 & 2.64 & 4.53 \\
2001 & -11.27 & 1664 & -12.75 & -7.70 & -6.75 & -5.21 \\
2002 & -20.84 & 1598 & -19.79 & -20.24 & -1.41 & -2.20 \\
2003 & 33.14 & 1518 & 29.09 & 33.85 & -0.61 & -0.21 \\
2004 & 13.00 & 1441 & 11.44 & 12.77 & 0.22 & 0.00 \\
2005 & 7.32 & 1363 & 8.29 & 9.62 & 0.45 & 0.57 \\
2006 & 16.22 & 1278 & 13.84 & 13.63 & -0.97 & -0.94 \\
2007 & 7.30 & 1217 & 6.94 & 8.34 & -0.63 & 0.81 \\
2008 & -38.31 & 1175 & -36.68 & -36.43 & -1.04 & -1.50 \\
2009 & 31.63 & 1113 & 28.44 & 28.59 & 0.23 & -0.30 \\
$1990-1994$ & 9.49 & 1670 & 11.10 & 11.83 & 0.47 & 0.49 \\
$1995-1999$ & 26.94 & 2453 & 24.87 & 23.56 & -0.82 & -0.97 \\
$2000-2004$ & 0.59 & 1817 & 1.32 & 4.31 & -1.18 & -0.62 \\
$2005-2009$ & 4.83 & 1386 & 4.16 & 4.75 & -0.40 & -0.27 \\
$1990-2009$ & 10.46 & 2913 & 10.36 & 11.11 & -0.48 & -0.34 \\
\hline
\end{tabular}




\section{Table 3: Individual Quality Signals: Annual Frequency}

This table indicates how each of the 14 metric values, across the four categories, is calculated. The metric values for each stock were adjusted by the population median, from the prior fiscal year. The metrics were not industry-adjusted in order to account for the impact of industry bets executed by the fund managers.

\begin{tabular}{|c|c|c|}
\hline Category & Signal & Measurement \\
\hline \multirow[t]{6}{*}{ Profitability } & Return on Equity (ROE) $)^{1}$ & $\frac{\text { Income before Extraordinary Items }}{\text { Shareholders: Equity }}$ (IB) \\
\hline & $\Delta \mathrm{ROE}^{2}$ & {$\left[\left(\mathrm{SEQ}_{\mathrm{t}-1}+\mathrm{ROE}_{\mathrm{t}}-\mathrm{ROE}_{\mathrm{t}-1}\right.\right.$} \\
\hline & $\mathrm{ROA}^{3}$ & Total Assets $\underline{\mathrm{IB}}_{\mathrm{t}-1}$ (AT) \\
\hline & $\Delta \mathrm{ROA}^{4}$ & {$\left[\frac{\mathrm{ROA}_{t}-\mathrm{ROA}_{\mathrm{t}-1}}{\left[\left(\mathrm{AT}_{\mathrm{t}-1}+\mathrm{AT}_{\mathrm{t}-2)}\right)\right.}{ }^{0.5}\right]$} \\
\hline & Operating Cash Flow (OCF) $)^{5}$ & $\frac{\text { Operating Activities - Net Cash Flow }}{\mathrm{t}}$ \\
\hline & Accruals (ACC) ${ }^{6}$ & 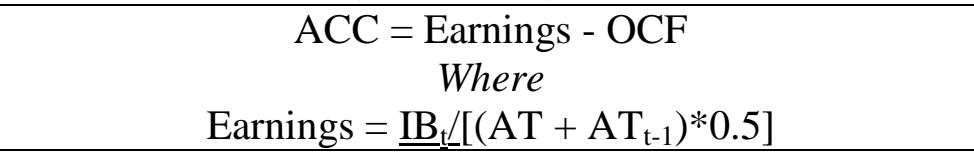 \\
\hline \multirow[t]{2}{*}{ Variability } & $\begin{array}{l}\text { Earnings Growth Variability } \\
(\text { ROA VAR })^{7}\end{array}$ & Variance of ROA over prior four years \\
\hline & $\begin{array}{l}\text { Sales Growth Variability } \\
\text { (SG VAR })^{8}\end{array}$ & $\begin{array}{c}\text { Variance of Sales Growth over prior four years } \\
\text { Where } \\
\text { Sales Growth }=\left(\text { Sales }_{t}-\text { Sales }_{\mathrm{t}-1}\right) / \text { Sales }_{\mathrm{t}-1} \\
\end{array}$ \\
\hline \multirow[t]{2}{*}{$\begin{array}{c}\text { Operating } \\
\text { Efficiency }\end{array}$} & Asset Turnover (ATO) ${ }^{9}$ & $\frac{\text { Sales }_{t}}{\mathrm{AT}_{\mathrm{t}-1}}$ \\
\hline & $\Delta \mathrm{ATO}^{10}$ & 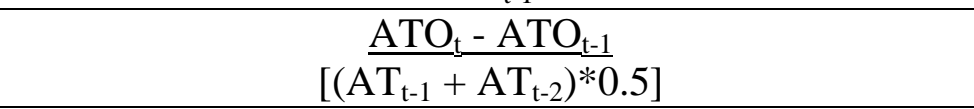 \\
\hline \multirow[t]{2}{*}{$\begin{array}{l}\text { Financial } \\
\text { Health }\end{array}$} & Leverage $(\mathrm{LEV})^{11}$ & $\frac{\text { Long Term Debt }}{\text { SEQ }_{t}}$ \\
\hline & Liquidity (LIQ) ${ }^{12}$ & $\begin{array}{c}\frac{\text { Working Capital }}{\text { AT }_{\mathrm{t}}} \\
\text { Where } \\
\text { Working Capital }=_{\text {Current Assets }}{ }_{\mathrm{t}}-\text { Current Liabilities }_{\mathrm{t}}\end{array}$ \\
\hline
\end{tabular}




\begin{tabular}{|c|c|c|}
\hline & $\Delta$ Shares Outstanding $(\Delta \mathrm{SH})^{13}$ & $\underline{\mathrm{SH}_{\mathrm{t}}-\mathrm{SH}_{\mathrm{t}-1}}$ \\
\hline & $\Delta$ Total Equity $(\Delta \mathrm{TE})^{14}$ & $\underline{\mathrm{SE}_{\mathrm{t}-1}} \frac{\mathrm{SH}}{\mathrm{TE}_{\mathrm{t}-1}-\frac{\mathrm{TE}}{\mathrm{t}-1} \frac{\mathrm{SH}}{\mathrm{t}-1} \underline{\mathrm{SH}}}$ \\
\hline
\end{tabular}

${ }^{\mathrm{I}}$ Taylor (2010, pers. comm., 10 Mar); Mercer (2010); Chen and Zhang (2007); Bird and Casavecchia (2007); Zhang (2000)

${ }^{2}$ Taylor (2010, pers. comm., 10 Mar); Bird and Casavecchia (2007)

${ }^{3}$ Taylor (2010, pers. comm., 10 Mar); Chen and Zhang, (2007); Bird and Casavecchia (2007); Mohanram (2005); Fairfield and Whisenant (2000); Piotroski (2000)

${ }^{4}$ Bird and Casavecchia (2007); Fairfield and Whisenant (2000); Piotroski (2000)

${ }^{5}$ Bird and Casavecchia (2007); Mohanram (2005); Piotroski (2000), Dechow and Dichev (2002)

${ }^{6}$ Chan et al.. (2006); Piotroski (2000); Hribar and Collins (2002); Dechow and Dichev (2002)

${ }^{7}$ Mercer (2010); Dichev and Tang (2009); Mohanram (2005)

${ }^{8}$ Mercer (2010); Mohanram (2005)

${ }_{9}^{9}$ Taylor (2010, pers. comm., 10 Mar); Bird and Casavecchia (2007)

${ }^{10}$ Bird and Casavecchia (2007); Piotroski (2000)

${ }^{11}$ George and Hwang (2010); Mercer (2010); Lui et al. (2007); Bird and Casavecchia (2007)

${ }_{13}^{12}$ Altman (1968)

${ }^{13}$ Donaldson (1961)

${ }^{14}$ Piotroski (2000); Modigliani and Miller (1958); Myers and Majluf (1984) 


\section{Table 4: Investing Measures for Quality Indicators}

This table presents mean values of the Investing Measures (IM) for each quality signal over the sample period. The metrics are Return on Equity (ROE), Change in ROE, Return on Assets (ROA), Change in ROA, Operating Cash Flow (OCF), Accruals (ACC), Asset Turnover (ATO), Change in ATO, Sales Growth Variability (SG VAR), ROA Variability (ROA VAR), Leverage (LEV), Liquidity (LIQ), Change in Shares Outstanding $(\triangle \mathrm{SH})$ and Change in Total Equity $(\triangle \mathrm{TE})$. The IM is defined as the weighted average decile rank of the individual stocks. The Compustat/CRSP/DGTW universe consists of all stocks with the data required to compute each metric. In this case the weight applied to each stock's decile rank is its market capitalisation as at December of year $t-1$, as a proportion of the total market capitalisation of all stocks in each metric's universe. The analysis is repeated on a subsample of stocks which are held by at least one mutual fund as at June of each year $t$. In this case a double-weighting approach is used which takes into account the market capitalisation weight of the stock and the funds' exposure to that stock as at June of year $t$. The comparison involves subtracting the IM for the universe from the mutual funds' IM. A positive (negative) difference indicates that mutual funds tilt their portfolios toward stocks with higher (lower) decile ranks on average. The $t$-statistic reported for the IMs is relative to an expected value of 5.50 based on an equally weighted average of the decile ranks. The $t$-statistic for the comparison of (1) and (2) is based on a paired sample $t$-test of the time-series means of the IMs over the sample period. The DGTW Alpha for each stock in the Compustat/CRSP/DGTW universe was regressed on the metric value for the stock as well as the metric value squared in order to capture any non-linear relationships, as per the following model: $y=\beta_{0}+\beta_{1} x+\beta_{2} x^{2}+\varepsilon$ over nine rolling time periods commencing in 1989 . The average of the nine coefficient estimates is provided- refer to Appendix B for a detailed summary of the estimates.

\begin{tabular}{|c|c|c|c|c|c|c|c|c|}
\hline \multicolumn{3}{|c|}{$\begin{array}{c}\text { Compustat/CRSP/DGTW Universe } \\
\text { (1) }\end{array}$} & \multicolumn{2}{|c|}{$\begin{array}{c}\text { Stocks held by Mutual } \\
\text { Funds (2) }\end{array}$} & \multicolumn{2}{|c|}{ Comparis on } & \multicolumn{2}{|c|}{$\begin{array}{c}\text { Average } \\
\text { Coefficient } \\
\text { Estimates }\end{array}$} \\
\hline Metric & $\begin{array}{l}\text { Mean Value- } \\
\text { Weighted IM }\end{array}$ & $t$-statistic & $\begin{array}{l}\text { Mean Value- } \\
\text { Weighted IM }\end{array}$ & $t$-statistic & (2) - (1) & $t$-statistic & $\beta_{1}$ & $\beta_{2}$ \\
\hline ROE & 7.57 & $52.64 * * * *$ & 7.17 & $21.49 * * * *$ & -0.40 & $-7.39 * * * *$ & 8.84 & -0.59 \\
\hline$\triangle \mathrm{ROE}$ & 5.83 & $4.75 * * * *$ & 5.78 & $4.29 * *$ & -0.05 & $-3.11 * * *$ & 1.06 & -11.49 \\
\hline ROA & 7.24 & $31.51 * * * *$ & 6.84 & $15.75 * * * *$ & -0.40 & $-7.08 * * * *$ & 21.29 & -2.06 \\
\hline$\triangle \mathrm{ROA}$ & 7.24 & $32.21 * * * *$ & 6.84 & $15.77 * * * *$ & -0.40 & $-7.28 * * * *$ & 20.17 & -3.35 \\
\hline $\mathrm{OCF}$ & 7.37 & $65.98 * * * *$ & 7.01 & $31.04 * * * *$ & -0.36 & $-7.61 * * * *$ & 37.00 & 14.94 \\
\hline $\mathrm{ACC}$ & 5.47 & -0.41 & 5.36 & $-1.86 *$ & -0.11 & $-7.22 * * * *$ & -10.74 & -115.04 \\
\hline ROA VAR & 3.69 & $-36.73 * * * *$ & 4.16 & $-31.29 * * * *$ & 0.47 & $8.64 * * * *$ & -50.84 & 29.27 \\
\hline SG VAR & 3.93 & $-16.21 * * * *$ & 4.35 & $-15.99 * * * *$ & 0.42 & $9.65 * * * *$ & -1.46 & 0.03 \\
\hline ATO & 5.08 & $-6.02 * * * *$ & 5.06 & -5.89 & -0.02 & $-0.63 * * * *$ & 1.69 & -0.97 \\
\hline$\triangle \mathrm{ATO}$ & 5.60 & 0.91 & 5.61 & 1.05 & 0.01 & 0.81 & -9.60 & -295.43 \\
\hline LEV & 6.43 & $19.85 * * * *$ & 6.30 & $12.87 * * * *$ & -0.13 & $-4.30 * *$ & 0.38 & -0.08 \\
\hline LIQ & 3.67 & $-47.93 * * * *$ & 3.85 & $-36.07 * * * *$ & 0.18 & $7.35 * * * *$ & 6.21 & -25.66 \\
\hline$\Delta \mathrm{SH}$ & 5.12 & $-2.47 * *$ & 5.29 & -1.53 & 0.17 & $4.74 * * * *$ & -7.52 & 0.10 \\
\hline$\Delta \mathrm{TE}$ & 5.66 & 1.46 & 5.60 & 0.95 & -0.06 & $-3.20 * * *$ & 1.03 & -0.97 \\
\hline
\end{tabular}

Statistical significance at the $0.1 \%, 1 \%, 5 \%$ and $10 \%$ levels is indicated by $* * * * * * *, * *$ and $*$, respectively. 
Table 5: Returns and Characteristics of Stocks by Q-Score Sorted Decile Portfolios

This table reports the mean values of returns and stock characteristics over the sample period for the stocks comprised in decile portfolios formed by sorting the universe of Compustat/CRSP/DGTW stocks, into equally-weighted portfolios in each year $t$ based on their Q-Scores. Decile 1 contains stocks with the lowest values of the Q-Score and decile 10 contains the stocks with the highest values of the Q-Score. The Q-Score has been computed as the aggregate of Return on Equity (ROE), Change in ROE, Return on Assets (ROA), Change in ROA, Operating Cash Flow, Accruals, Sales Growth Variability, ROA Variability, Asset Turnover (ATO), Change in ATO, Leverage, Liquidity, Change in Shares Outstanding and in ROA, Operating Cash Flow, Accruals, Sales Growth Variability, ROA Variability, Asset Turnover (ATO), Change in ATO, Leverage, Liquidity, Change in Shares Outstanding and Compustat/CRSP/DGTW universe was regressed on the metric value for each stock as well as the metric value squared in order to capture any non-linear relationships, as per the following model: $y=\beta_{0}+\beta_{1} x+\beta_{2} x^{2}+\varepsilon$. The regressions were run over rolling time periods - the first regression was run using the estimation period 1989-1998, the parameter estimates obtained were then used to calculate each metric's contribution to the Q-Score using the metric values for 1999. The Q-Score for 1999 was then merged with the mutual fund holdings as at June of 2000 , and alpha was examined from July 2000-June 2001. The means for section A are obtained by value-weighting the returns and characteristics for each stock in the decile by its market capitalisation as at December of year $t$-1.The analysis is repeated using a double-weighting approach in order to account for both a stock's share of the market and the level of exposure that mutual funds have to that stock. Section B reports the results using this methodology. No. of stocks is the average number of stocks contained in each decile portfolio over the sample period. Size is the mean market capitalisation of each stock in the portfolio, as at December of year $t-1$. Raw return volatility is the mean annualised standard deviation of the unadjusted monthly returns from July of year $t$ to June of year $t+l$ for each stock in the portfolio. Q-Score value is the mean value of the given metric per decile portfolio over the sample period. The mow benty CRSP

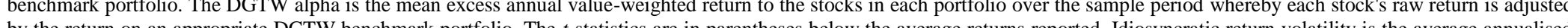

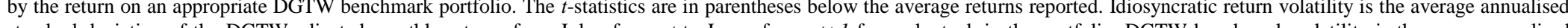
standard deviation of the DGTW-adjusted monthly returns from July of year $t$ to June of year $t+1$ for each stock in the portfolio. DGTW benchmark volatility is the mean annualised volatility of the monthly returns from July of year $t$ to June of year $t+1$ for each stock's DGTW benchmark portfolio.

\begin{tabular}{|c|c|c|c|c|c|c|c|c|c|c|c|c|c|c|c|c|}
\hline \multicolumn{9}{|c|}{ A: Compustat/CRSP/DGTW Universe } & \multicolumn{8}{|c|}{ B: Mutual Fund Holdings } \\
\hline $\begin{array}{l}\text { Decile } \\
\text { Portfolios }\end{array}$ & $\begin{array}{l}\text { No. of } \\
\text { Stocks }\end{array}$ & $\begin{array}{c}\text { Size } \\
\text { (\$ Million) }\end{array}$ & $\begin{array}{l}\text { Q-Score } \\
\text { Value }\end{array}$ & $\begin{array}{l}\text { Raw } \\
\text { Return } \\
(\%)\end{array}$ & $\begin{array}{c}\text { DGTW } \\
\text { Alpha } \\
(\%)\end{array}$ & $\begin{array}{c}\text { Raw } \\
\text { Return } \\
\text { Volatility } \\
(\%)\end{array}$ & $\begin{array}{c}\text { Idiosyncratic } \\
\text { Return } \\
\text { Volatility } \\
(\%)\end{array}$ & $\begin{array}{c}\text { DGTW } \\
\text { Benchmark } \\
\text { Volatility } \\
(\%)\end{array}$ & $\begin{array}{l}\text { No. of } \\
\text { Stocks }\end{array}$ & $\begin{array}{c}\text { Size } \\
\text { (\$ Million) }\end{array}$ & $\begin{array}{l}\text { Q-Score } \\
\text { Value }\end{array}$ & $\begin{array}{l}\text { Raw } \\
\text { Return } \\
(\%)\end{array}$ & $\begin{array}{c}\text { DGTW } \\
\text { Alpha } \\
(\%)\end{array}$ & $\begin{array}{c}\text { Raw } \\
\text { Return } \\
\text { Volatility } \\
(\%)\end{array}$ & $\begin{array}{c}\text { Idiosyncratic } \\
\text { Return } \\
\text { Volatility } \\
(\%)\end{array}$ & $\begin{array}{c}\text { DGTW } \\
\text { Benchmark } \\
\text { Volatility } \\
(\%)\end{array}$ \\
\hline $\begin{array}{c}\text { P1 } \\
\text { (Low) }\end{array}$ & 262 & 360 & -48.91 & $\begin{array}{l}-17.19 \\
(-1.60)\end{array}$ & $\begin{array}{c}-14.57^{* * *} \\
(-2.32)\end{array}$ & 67.91 & 59.88 & 25.49 & 202 & 460 & -47.64 & $\begin{array}{l}-17.45 \\
(-1.62)\end{array}$ & $\begin{array}{r}-14.77 * \\
(-2.27)\end{array}$ & 64.05 & 55.98 & 25.05 \\
\hline P2 & 262 & 668 & -15.64 & $\begin{array}{c}1.01 \\
(0.15)\end{array}$ & $\begin{array}{c}-0.93 \\
(-0.27)\end{array}$ & 47.14 & 41.47 & 22.47 & 214 & 792 & -15.57 & $\begin{array}{c}1.09 \\
(0.16)\end{array}$ & $\begin{array}{c}-0.55 \\
(-0.16)\end{array}$ & 44.90 & 39.48 & 21.70 \\
\hline P3 & 262 & 1,528 & -6.63 & $\begin{array}{c}0.53 \\
(0.07)\end{array}$ & $\begin{array}{l}-0.13 \\
(-0.04)\end{array}$ & 42.96 & 36.27 & 20.18 & 226 & 1,749 & -6.71 & $\begin{array}{c}-0.01 \\
(-0.00)\end{array}$ & $\begin{array}{c}-1.32 \\
(-0.51)\end{array}$ & 41.54 & 35.50 & 20.04 \\
\hline P4 & 263 & 2,115 & -2.64 & $\begin{array}{c}0.32 \\
(0.06)\end{array}$ & $\begin{array}{c}0.01 \\
(0.00)\end{array}$ & 34.17 & 29.60 & 19.64 & 238 & 2,355 & -2.65 & $\begin{array}{c}-0.59 \\
(-0.11)\end{array}$ & $\begin{array}{c}-0.76 \\
(-0.46)\end{array}$ & 34.36 & 29.42 & 19.42 \\
\hline P5 & 262 & 2,387 & -0.09 & $\begin{array}{c}5.86 \\
(0.96)\end{array}$ & $\begin{array}{c}2.50 \\
(1.53)\end{array}$ & 31.37 & 26.32 & 17.90 & 237 & 2,598 & -0.05 & $\begin{array}{c}5.30 \\
(0.82)\end{array}$ & $\begin{array}{c}2.71 \\
(1.61)\end{array}$ & 31.03 & 26.27 & 17.81 \\
\hline P6 & 262 & 2,436 & 2.02 & $\begin{array}{c}2.85 \\
(0.53)\end{array}$ & $\begin{array}{l}2.18 \\
(1.64)\end{array}$ & 30.48 & 25.83 & 17.90 & 242 & 2,630 & 2.03 & $\begin{array}{l}2.58 \\
(0.43)\end{array}$ & $\begin{array}{c}1.75 \\
(1.33)\end{array}$ & 31.43 & 26.52 & 18.49 \\
\hline P7 & 263 & 2,647 & 4.11 & $\begin{array}{c}3.20 \\
(0.54)\end{array}$ & $\begin{array}{c}0.57 \\
(0.58)\end{array}$ & 32.69 & 27.29 & 17.92 & 246 & 2,820 & 4.09 & $\begin{array}{c}3.59 \\
(0.60)\end{array}$ & $\begin{array}{c}1.07 \\
(0.87)\end{array}$ & 33.66 & 28.29 & 18.25 \\
\hline P8 & 262 & 3,826 & 6.39 & $\begin{array}{c}2.67 \\
(0.59)\end{array}$ & $\begin{array}{l}4.11^{*} \\
(2.16)\end{array}$ & 28.57 & 24.63 & 17.54 & 247 & 4,045 & 6.34 & $\begin{array}{c}1.64 \\
(0.32)\end{array}$ & $\begin{array}{l}3.15^{*} \\
(1.95)\end{array}$ & 30.87 & 26.15 & 18.36 \\
\hline P9 & 262 & 4,419 & 9.08 & $\begin{array}{c}2.64 \\
(0.54)\end{array}$ & $\begin{array}{c}2.45 \\
(1.18)\end{array}$ & 29.09 & 25.01 & 17.38 & 249 & 4,627 & 9.06 & $\begin{array}{l}2.91 \\
(0.54)\end{array}$ & $\begin{array}{l}2.98 \\
(1.46)\end{array}$ & 30.78 & 26.58 & 18.12 \\
\hline $\begin{array}{l}\text { P10 } \\
\text { (High) }\end{array}$ & 262 & 6,403 & 15.46 & $\begin{array}{c}-0.63 \\
(-0.15) \\
\end{array}$ & $\begin{array}{c}-0.50 \\
(-0.37) \\
\end{array}$ & 28.84 & 23.92 & 17.42 & 249 & 6,715 & 15.34 & $\begin{array}{c}-1.47 \\
(-0.30)\end{array}$ & $\begin{array}{c}-0.34 \\
(-0.27)\end{array}$ & 31.37 & 25.86 & 18.38 \\
\hline
\end{tabular}




\section{Table 6: Mean Fund Returns \& Characteristics of Q-Score sorted Deciles}

This table presents the mean returns to deciles containing mutual funds which have been sorted based on the weightedaverage Q-Score for their portfolios. Firstly, in June of each year $t$ the Q-Score for each stock is computed and then the weighted-average Q-Score is computed for each fund based on the holding value of each stock as at June of year $t$. Subsequently, the equally-weighted mean Q-Score across the funds is computed each quarter and then these four quarterly values are averaged each year. The time-series mean over the sample period is reported below. The mean returns are computed in a similar fashion to the stock returns in Table 4 i.e., the deciles are formed in June of each year $t$ and then the returns are calculated from July of year $t$ to June of year $t+1$. All funds with holdings data available in a given quarter of each portfolio formation year are included in the calculation of the mean annual return for that portfolio formation year. Therefore, the results are free from survivorship bias as the mean return for the funds is calculated on a quarterly basis and then the annual return is the compound of these four mean returns. The time-series means of the annual raw and DGTW-adjusted returns are reported below. The mean size, book-to-market and momentum quintiles to which the stocks were assigned based on the DGTW approach are also provided. Firstly, the asset-weighted mean quintile per quarter, each year, across the deciles is calculated. Then the mean of the four quarterly values is calculated each year. The mean quintiles reported below are the time-series means over the sample period. Finally, the proportions of funds which are members of each of the three Investment Objective Code groups included in the study are provided.

\begin{tabular}{|c|c|c|c|c|c|c|c|c|c|}
\hline Decile & Q-Score & $\begin{array}{c}\text { Annual Raw } \\
\text { Return } \\
(\%)\end{array}$ & $\begin{array}{c}\text { Annual } \\
\text { DGTW-Adjusted } \\
\text { Return (\%) }\end{array}$ & $\begin{array}{c}\text { Size } \\
\text { Quintile }\end{array}$ & $\begin{array}{c}\text { Book-to- } \\
\text { Market } \\
\text { Quintile }\end{array}$ & $\begin{array}{l}\text { Momentum } \\
\text { Quintile }\end{array}$ & $\begin{array}{l}\text { Aggressive } \\
\text { Growth } \\
(\%)\end{array}$ & $\begin{array}{c}\text { Growth } \\
(\%)\end{array}$ & $\begin{array}{c}\text { Growth \& } \\
\text { Income } \\
(\%)\end{array}$ \\
\hline $\begin{array}{c}\text { P1 } \\
\text { (Low) }\end{array}$ & -3.80 & $\begin{array}{c}2.17 \\
(-0.31)\end{array}$ & $\begin{array}{c}-3.35 * * \\
(-2.50)\end{array}$ & 3.64 & 2.60 & 3.18 & 14.70 & 73.70 & 11.60 \\
\hline $\mathrm{P} 2$ & 1.33 & $\begin{array}{l}-0.27 \\
(-0.04)\end{array}$ & $\begin{array}{l}-1.39 * \\
(-2.24)\end{array}$ & 4.07 & 2.86 & 3.02 & 10.27 & 74.82 & 14.91 \\
\hline P3 & 2.81 & $\begin{array}{c}1.11 \\
(0.18)\end{array}$ & $\begin{array}{l}-0.80 \\
(-1.07)\end{array}$ & 4.19 & 2.86 & 2.97 & 10.73 & 68.87 & 20.40 \\
\hline $\mathrm{P} 4$ & 3.82 & $\begin{array}{c}1.17 \\
(0.19)\end{array}$ & $\begin{array}{c}0.43 \\
(0.59)\end{array}$ & 4.48 & 2.84 & 2.97 & 9.87 & 68.46 & 21.68 \\
\hline P5 & 4.61 & $\begin{array}{c}0.69 \\
(0.12)\end{array}$ & $\begin{array}{c}0.08 \\
(0.12)\end{array}$ & 4.63 & 2.84 & 2.88 & 8.07 & 62.98 & 28.95 \\
\hline P6 & 5.31 & $\begin{array}{l}-1.16 \\
(-0.21)\end{array}$ & $\begin{array}{l}-1.03 \\
(-1.60)\end{array}$ & 4.65 & 2.65 & 2.95 & 7.94 & 65.49 & 26.57 \\
\hline P7 & 5.99 & $\begin{array}{l}-1.54 \\
(-0.26)\end{array}$ & $\begin{array}{l}-1.22 \\
(-1.72)\end{array}$ & 4.67 & 2.54 & 2.99 & 7.67 & 65.52 & 26.81 \\
\hline P8 & 6.66 & $\begin{array}{l}-1.27 \\
(-0.23)\end{array}$ & $\begin{array}{l}-1.67 * \\
(-1.93)\end{array}$ & 4.72 & 2.50 & 2.97 & 6.66 & 64.93 & 28.41 \\
\hline P9 & 7.45 & $\begin{array}{l}-1.67 \\
(-0.32)\end{array}$ & $\begin{array}{l}-1.33 \\
(-1.67)\end{array}$ & 4.75 & 2.44 & 2.95 & 5.51 & 68.66 & 25.83 \\
\hline $\begin{array}{c}\text { P10 } \\
\text { (High) }\end{array}$ & 9.29 & $\begin{array}{c}-0.74 \\
(-0.16)\end{array}$ & $\begin{array}{l}-0.76 \\
(-0.81)\end{array}$ & 4.68 & 2.35 & 2.93 & 7.52 & 79.33 & 13.16 \\
\hline
\end{tabular}

Statistical significance at the $0.1 \%, 1 \%, 5 \%$ and $10 \%$ levels is indicated by $* * * * * * * * *$ and $*$, respectively. 
Table 7: Mean Q-Score \& DGTW-Adjusted Fund Returns over Sample Period

This table presents the mean DGTW-adjusted fund returns, per decile, in each year over the sample period. The year indicates the Portfolio Formation Year (PFY) e.g. 2000 comprises the four quarters commencing from July 2000 to June 2001. The annual return reported is the compound of the four mean quarterly returns for the year. Therefore every fund which existed in each quarter is included and so the mean annual return is free from survivorship bias. The corresponding mean Q-Score for the funds in each decile is also provided below the mean returns in italics. N.B. the Q-Score for 1999 is associated with the DGTW-adjusted return for PFY 2000. So the Q. Scores range from 1999-2007, whilst the returns range from PFY 2000-2008. The $t$-statistics are in parentheses below the time-series average of the yearly returns. Volatility is the standard deviation of the mean annual returns over the sample period.

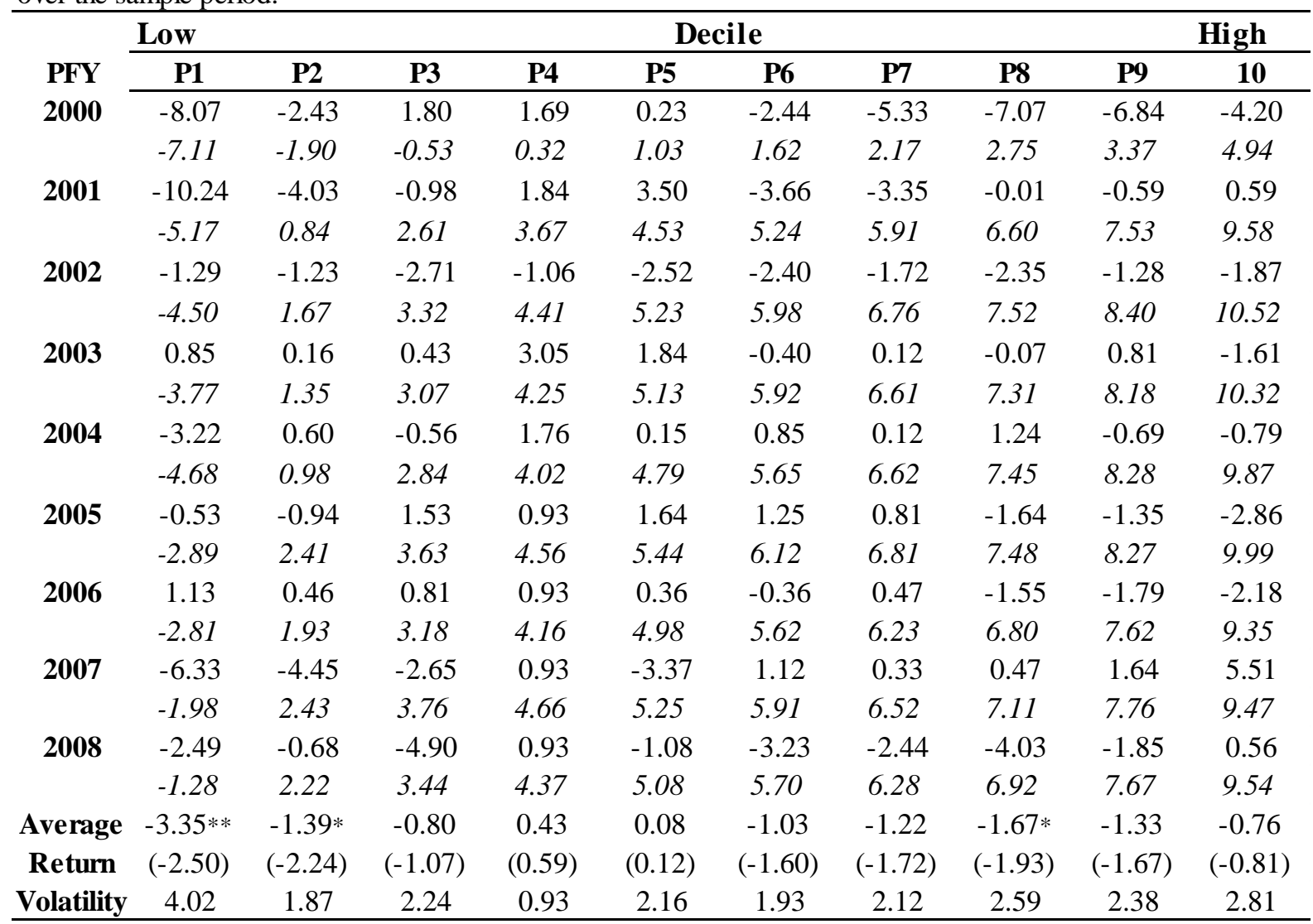

Statistical significance at the $0.1 \%, 1 \%, 5 \%$ and $10 \%$ levels is indicated by $* * * * * * *, * *$ and $*$, respectively. 
Table 8: Mean Returns \& Fund Characteristics of Q-Score sorted Deciles for MFLINKS Subset

The Thomson Reuters Institutional Holdings (13F) database was merged with the CRSP Mutual Fund Database (CMFD) using MFLINKS, these results are based on the subset of funds which were able to be merged. This table presents the mean returns to deciles containing mutual funds which have been sorted based on the weighted-average Q-Score for their portfolios. Firstly, in June of each year $t$ the Q-Score for each stock is computed and then the weighted-average Q-Score is computed for each fund based on the holding value of each stock as at June of year $t$. Subsequently, the equally-weighted mean Q-Score across the funds is computed each quarter and then these four quarterly values are averaged each year. The time-series mean over the sample period is reported below. The mean returns are computed in a similar fashion to the stock returns in Table 5 i.e., the deciles are formed in June of each year $t$ and then the returns are calculated from July of year $t$ to June of year $t+1$. All funds with holdings data available in a given quarter of each portfolio formation year are included in the calculation of the mean annual return for that portfolio formation year. Therefore, the results are free from survivorship bias as the mean return for the funds is calculated on a quarterly basis and then the annual return is the compound of these four mean returns. The time-series means of the annual raw and DGTW-adjusted returns are reported below. The mean size, book-to-market and momentum quintiles to which the stocks were assigned based on the DGTW approach are also provided. Firstly, the assetweighted mean quintile per quarter, each year, across the deciles is calculated. Then the mean of the four quarterly values is calculated each year. The mean quintiles reported below are the time-series means over the sample period. The proportions of funds which are members of each of the three Investment Objective Code groups included in the study are also provided. Finally, the mean values of various fund characteristics sourced from the CMFD are provided, as at June of year $t$. Turnover Ratio is the minimum (of aggregated sales or aggregated purchases of securities), divided by the average 12-month Total Net Assets of the fund. Fees represents the Management Fee (\$) divided by Average Net Assets (\$). The Expense Ratio is the ratio of the total investment that shareholders pay for the fund's operating expenses. Age is the number of years since the fund was first offered. Total Net Assets is as of month-end i.e., June of year $t$.

\begin{tabular}{|c|c|c|c|c|c|c|c|c|c|c|c|c|c|c|}
\hline Decile & Q-Score & $\begin{array}{c}\text { Annual Raw } \\
\text { Return } \\
(\%)\end{array}$ & $\begin{array}{c}\text { Annual } \\
\text { DGTW-Adjusted } \\
\text { Return }(\%)\end{array}$ & $\begin{array}{c}\text { Size } \\
\text { Quintile }\end{array}$ & $\begin{array}{c}\text { Book-to- } \\
\text { Market } \\
\text { Quintile }\end{array}$ & $\begin{array}{l}\text { Momentum } \\
\text { Quintile }\end{array}$ & $\begin{array}{c}\text { Aggressive } \\
\text { Growth } \\
(\%)\end{array}$ & $\begin{array}{c}\text { Growth } \\
(\%)\end{array}$ & $\begin{array}{c}\text { Growth \& } \\
\text { Income } \\
(\%)\end{array}$ & $\begin{array}{c}\text { Turnover } \\
\text { Ratio } \\
(\%)\end{array}$ & Fees & $\begin{array}{c}\text { Expense } \\
\text { Ratio }\end{array}$ & $\begin{array}{c}\text { Age } \\
\text { (Years) }\end{array}$ & $\begin{array}{c}\text { Total Net } \\
\text { Assets } \\
\text { (\$ Millions) }\end{array}$ \\
\hline $\begin{array}{c}\text { P1 } \\
\text { (Low) }\end{array}$ & -4.17 & $\begin{array}{c}-0.55 \\
(-0.31)\end{array}$ & $\begin{array}{l}-2.35^{*} \\
(-1.96)\end{array}$ & 3.46 & 2.59 & 3.24 & 15.58 & 73.79 & 10.63 & 122.13 & 0.76 & 1.86 & 15.33 & 720 \\
\hline $\mathrm{P} 2$ & 1.17 & $\begin{array}{l}-1.37 \\
(-0.04)\end{array}$ & $\begin{array}{l}-2.39 * * \\
(-2.30)\end{array}$ & 3.87 & 2.70 & 3.00 & 13.91 & 75.14 & 10.95 & 98.21 & 0.80 & 1.32 & 15.17 & 1185 \\
\hline P3 & 2.79 & $\begin{array}{c}4.58 \\
(0.18)\end{array}$ & $\begin{array}{c}1.08 \\
(0.97)\end{array}$ & 4.07 & 2.87 & 3.07 & 13.99 & 66.06 & 19.95 & 96.76 & 0.76 & 1.26 & 17.31 & 1818 \\
\hline P4 & 3.85 & $\begin{array}{c}0.63 \\
(0.19)\end{array}$ & $\begin{array}{l}-0.37 \\
(-0.30)\end{array}$ & 4.28 & 2.85 & 3.02 & 9.93 & 67.55 & 22.52 & 92.68 & 0.73 & 1.24 & 15.17 & 1523 \\
\hline P5 & 4.66 & $\begin{array}{l}-0.33 \\
(0.12)\end{array}$ & $\begin{array}{l}-1.13 \\
(-1.50)\end{array}$ & 4.29 & 2.78 & 3.03 & 12.10 & 65.07 & 22.83 & 89.58 & 0.76 & 1.25 & 16.14 & 1171 \\
\hline P6 & 5.36 & $\begin{array}{l}-1.75 \\
(-0.21)\end{array}$ & $\begin{array}{l}-1.75 \\
(-1.80)\end{array}$ & 4.50 & 2.50 & 3.00 & 11.92 & 69.74 & 18.34 & 83.87 & 0.76 & 1.30 & 16.74 & 1463 \\
\hline P7 & 6.08 & $\begin{array}{l}-0.87 \\
(-0.26)\end{array}$ & $\begin{array}{l}-0.72 \\
(-0.65)\end{array}$ & 4.53 & 2.49 & 2.99 & 6.60 & 68.15 & 25.26 & 74.63 & 0.70 & 1.10 & 18.22 & 1170 \\
\hline P8 & 6.79 & $\begin{array}{l}-2.47 \\
(-0.23)\end{array}$ & $\begin{array}{l}-2.80 \\
(-1.65)\end{array}$ & 4.61 & 2.43 & 3.05 & 6.92 & 65.16 & 27.92 & 77.94 & 0.71 & 1.11 & 18.57 & 1674 \\
\hline P9 & 7.69 & $\begin{array}{c}1.87 \\
(-0.32)\end{array}$ & $\begin{array}{c}0.10 \\
(0.08)\end{array}$ & 4.59 & 2.47 & 2.93 & 7.72 & 69.01 & 23.27 & 65.33 & 0.72 & 1.21 & 21.04 & 1850 \\
\hline $\begin{array}{c}\text { P10 } \\
\text { (High) }\end{array}$ & 9.64 & $\begin{array}{c}1.05 \\
(-0.16) \\
\end{array}$ & $\begin{array}{c}0.03 \\
(0.02) \\
\end{array}$ & 4.64 & 2.53 & 2.82 & 9.95 & 76.26 & 13.79 & 53.05 & 0.82 & 1.23 & 20.87 & 718 \\
\hline
\end{tabular}

Statistical significance at the $0.1 \%, 1 \%, 5 \%$ and $10 \%$ levels is indicated by $* * * *, * * *, * *$ and $*$, respectively 


\section{Appendix A}

Database Construction

The s12 dataset provides information on mutual funds which is divided into distinct table 'types':

1. Section 12 (from the SEC form) Type 1 Table - Fund Characteristics

2. Section 12 Type 2 Table - Stock Characteristics

3. Section 12 Type 3 Table - Holdings

4. Section 12 Type 4 Table - Change in Holdings

In order to account for the fact that Thomson Reuters carries forward stale holdings data where subsequent quarters are missing; only the first vintage date (FDATE) with holdings data for each report date (RDATE)-fund number (FUNDNO) combination was selected (Kacperzczyk et al., 2008). This data was then merged with the Type 3 holdings data table based on the FUNDNO and FDATE.

The required stock characteristic information was obtained from CRSP (via WRDS) as opposed to the S12 Type 2 table due to the fact that the stock price series in some cases are stale; representing the closing price of the prior quarter especially in 1999 and 2000 data. The CRSP universe was limited to stocks with share codes 10 and 11 which apply to common stocks of US firms. The adjusted prices were computed by dividing the absolute value of the raw prices by the 'Cumulative Factor to Adjust Prices'. It is necessary to take the absolute value of the price as the negative average of the bid and ask price is used when the closing price is missing. The variable Total Shares Outstanding, Adjusted (TSO) was computed as follows; Number of Shares Outstanding*Cumulative Factor to Adjust Shares (CFACSHR)*1,000. All values for which TSO was not greater than zero were deleted.

The CRSP dataset was merged with the holdings data by mapping the Thomson Reuters historical Committee on Uniform Security Identification Procedures (CUSIP) identifier to the CRSP unique Permanent Security Identification Number (PERMNO) when the FDATE and CRSP date were equal. The FDATE is the vintage filing date and it is not the date for which the holdings data is valid- that date is the RDATE. Holding adjustments are made for stock splits, stock distributions, mergers and acquisitions and other corporate events, such that the number of shares held (SHARES) values are adjusted for stock splits that occur between the 
RDATE and FDATE. Thus, it is necessary to adjust the SHARES values as of the FDATE. It is a well-known issue with the s12 database that the stock level adjustments are made at the end of the quarter as per the FDATE and these adjustments cannot always be synchronised with the RDATE. Whereas, the stock price data from CRSP is linked to the holdings data using the RDATE as this is the date for which the holdings are valid. Specifically, the adjusted shares held values were calculated by multiplying the SHARES values by the CFACSHR.

The holdings snapshots were assigned to calendar quarters based on the month of the RDATE which is consistent with Wermers (2000) and it is appropriate given that the majority of funds report their holdings as per the calendar quarters.

The fund returns were calculated by value-weighting the returns to the stock holdings each quarter. The quarterly return for each stock was computed using simple compounding of the component month buy-and-hold returns obtained from CRSP. In order to ensure that extreme values did not influence the results the quarterly stock returns were winsorised at the $1^{\text {st }}$ and $99^{\text {th }}$ percentiles. The weight applied to each stock is its holding value as at the end of the prior quarter, divided by the fund's contemporaneous portfolio value. Thus, these weights are normalised so that the sum of the weights equals 1. Specifically, the holding value is the product of the adjusted shares held and the stock price at the end of the prior quarter and only observations where the holding value was greater than zero were retained.

In order to compute the DGTW-adjusted fund returns each stock was assigned to its characteristic matched benchmark portfolio and the quarterly return to this portfolio was subtracted from the stock's raw return. The excess quarterly stock returns and the raw and excess quarterly fund returns were winsorised at the $1^{\text {st }}$ and $99^{\text {th }}$ percentiles.

Furthermore, given that the stock weights applied are as at the end of the prior quarter the holdings snapshots are assigned to calendar quarters as follows;

- If the month of the RDATE is October, November or December of year $t$ - 1 then these are the stock weights used to compute the fund returns for quarter 1 of year $t$.

- If the month of the RDATE is January, February or March of year $t$ then these are the stock weights used to compute the fund returns for quarter 2 of year $t$. 
- If the month of the RDATE is April, May or June of year $t$ then these are the stock weights used to compute the fund returns for quarter 3 of year $t$.

- If the month of the RDATE is July, August or September of year $t$ then these are the stock weights used to compute the fund returns for quarter 4 of year $t$.

If there was more than one holdings report filed by a fund in a given quarter then only the most recent holdings snapshot was retained. The dollar value of assets under management at the end of the quarter and the corresponding stock counts were computed. All funds with portfolio assets less than $\$ 5$ million and those which held less than ten stocks as at the end of the quarter were subsequently excluded (Kacperzczyk et al., 2008). The assets and number of stocks values were winsorised at the $99^{\text {th }}$ percentile, given that the minimum values were already established. 


\section{Appendix B: Rolling Regression Results}

The following table summarises the results from performing univariate regressions of alpha on each metric value and its square. The regressions were run over rolling time periods- the first regression was run using the estimation period 1989-1998 (subset 1), the parameter estimates obtained were then used to calculate each metric's contribution to the Q-Score using the metric values for 1999. The Q-Score for 1999 was then merged with the mutual fund holdings as at June of 2000, and alpha was examined from July 2000-June 2001. Essentially, this allows the predictive capability of the Q-Score constructed to be examined without the impact of any hindsight biases. The second regression was run using data from 1989-1999, the third from 1989-2000 and so on up to an estimation period of 1989-2006 (subset 9). Thus, the parameter estimates for each of the nine regressions were used on the associated metric values for the following year . Overall, the QScore was calculated for nine years ranging from 1999-2007 and the associated DGTW alpha was examined over nine periods from July 2000-June 2009. The regression model is as follows: $y=\beta_{0}+\beta_{1} x+\beta_{2} x^{2}+\varepsilon$.

\begin{tabular}{|c|c|c|c|c|c|c|c|c|c|}
\hline Subset & $\beta_{1}$ & $\begin{array}{c}\text { Standard } \\
\text { Error }\end{array}$ & $\begin{array}{c}t- \\
\text { statistic }\end{array}$ & $p$-value & $\boldsymbol{\beta}_{2}$ & $\begin{array}{c}\text { Standard } \\
\text { Error }\end{array}$ & $\begin{array}{c}t- \\
\text { statistic }\end{array}$ & $p$-value & $\begin{array}{c}\text { Year } \beta_{1} \& \\
\beta_{2} \text { Applied } \\
\text { to Metric } \\
\text { Value }\end{array}$ \\
\hline \multicolumn{10}{|c|}{ Return on Equity (ROE) } \\
\hline 1 & 5.85 & 0.86 & 6.81 & $<.0001$ & -1.31 & 0.46 & -2.85 & 0.00 & 1999 \\
\hline 2 & 7.96 & 0.83 & 9.65 & $<.0001$ & -0.89 & 0.44 & -2.04 & 0.04 & 2000 \\
\hline 3 & 9.77 & 0.78 & 12.47 & $<.0001$ & -0.55 & 0.41 & -1.34 & 0.18 & 2001 \\
\hline 4 & 9.15 & 0.75 & 12.19 & $<.0001$ & -0.51 & 0.40 & -1.28 & 0.20 & 2002 \\
\hline 5 & 9.12 & 0.73 & 12.54 & $<.0001$ & -0.53 & 0.39 & -1.36 & 0.17 & 2003 \\
\hline 6 & 9.53 & 0.70 & 13.64 & $<.0001$ & -0.43 & 0.37 & -1.15 & 0.25 & 2004 \\
\hline 7 & 9.51 & 0.68 & 14.08 & $<.0001$ & -0.35 & 0.36 & -0.96 & 0.34 & 2005 \\
\hline 8 & 9.38 & 0.65 & 14.35 & $<.0001$ & -0.33 & 0.35 & -0.94 & 0.35 & 2006 \\
\hline 9 & 9.28 & 0.63 & 14.69 & $<.0001$ & -0.43 & 0.34 & -1.28 & 0.20 & 2007 \\
\hline \multicolumn{10}{|c|}{ Change in ROE } \\
\hline 1 & 1.58 & 1.12 & 1.42 & 0.16 & -10.61 & 1.02 & -10.44 & $<.0001$ & 1999 \\
\hline 2 & 1.41 & 1.10 & 1.29 & 0.20 & -11.33 & 1.00 & -11.36 & $<.0001$ & 2000 \\
\hline 3 & 0.84 & 1.06 & 0.79 & 0.43 & -11.96 & 0.96 & -12.39 & $<.0001$ & 2001 \\
\hline 4 & 1.08 & 1.04 & 1.03 & 0.30 & -11.33 & 0.94 & -11.99 & $<.0001$ & 2002 \\
\hline 5 & 0.98 & 1.03 & 0.95 & 0.34 & -11.60 & 0.93 & -12.42 & $<.0001$ & 2003 \\
\hline 6 & 1.02 & 1.00 & 1.01 & 0.31 & -11.69 & 0.91 & -12.84 & $<.0001$ & 2004 \\
\hline 7 & 0.95 & 0.99 & 0.96 & 0.34 & -11.54 & 0.89 & -12.90 & $<.0001$ & 2005 \\
\hline 8 & 0.82 & 0.97 & 0.84 & 0.40 & -11.63 & 0.88 & -13.25 & $<.0001$ & 2006 \\
\hline 9 & 0.86 & 0.95 & 0.90 & 0.37 & -11.72 & 0.86 & -13.60 & $<.0001$ & 2007 \\
\hline \multicolumn{10}{|c|}{ Return on Assets (ROA) } \\
\hline 1 & 15.41 & 2.09 & 7.38 & $<.0001$ & -5.23 & 2.61 & -2.00 & 0.05 & 1999 \\
\hline 2 & 20.69 & 2.00 & 10.34 & $<.0001$ & -1.63 & 2.47 & -0.66 & 0.51 & 2000 \\
\hline 3 & 24.24 & 1.89 & 12.81 & $<.0001$ & -0.93 & 2.29 & -0.41 & 0.68 & 2001 \\
\hline 4 & 21.40 & 1.81 & 11.83 & $<.0001$ & -1.55 & 2.20 & -0.70 & 0.48 & 2002 \\
\hline 5 & 20.87 & 1.75 & 11.93 & $<.0001$ & -2.42 & 2.14 & -1.13 & 0.26 & 2003 \\
\hline 6 & 22.54 & 1.68 & 13.41 & $<.0001$ & -1.27 & 2.05 & -0.62 & 0.54 & 2004 \\
\hline 7 & 22.01 & 1.63 & 13.54 & $<.0001$ & -2.04 & 1.99 & -1.02 & 0.31 & 2005 \\
\hline 8 & 21.93 & 1.57 & 13.94 & $<.0001$ & -2.09 & 1.93 & -1.08 & 0.28 & 2006 \\
\hline 9 & 22.50 & 1.52 & 14.78 & $<.0001$ & -1.36 & 1.87 & -0.73 & 0.47 & 2007 \\
\hline \multicolumn{10}{|c|}{ Change in ROA } \\
\hline 1 & 15.44 & 1.97 & 7.83 & $<.0001$ & -5.43 & 2.61 & -2.08 & 0.04 & 1999 \\
\hline 2 & 20.64 & 1.89 & 10.91 & $<.0001$ & -1.77 & 2.46 & -0.72 & 0.47 & 2000 \\
\hline 3 & 23.70 & 1.80 & 13.19 & $<.0001$ & -1.63 & 2.29 & -0.71 & 0.48 & 2001 \\
\hline 4 & 20.67 & 1.72 & 12.02 & $<.0001$ & -2.32 & 2.20 & -1.05 & 0.29 & 2002 \\
\hline 5 & 19.52 & 1.67 & 11.69 & $<.0001$ & -3.89 & 2.14 & -1.82 & 0.07 & 2003 \\
\hline 6 & 20.64 & 1.61 & 12.82 & $<.0001$ & -3.36 & 2.06 & -1.63 & 0.10 & 2004 \\
\hline 7 & 20.05 & 1.56 & 12.85 & $<.0001$ & -4.22 & 2.00 & -2.11 & 0.03 & 2005 \\
\hline 8 & 20.07 & 1.51 & 13.30 & $<.0001$ & -4.18 & 1.94 & -2.16 & 0.03 & 2006 \\
\hline 9 & 20.74 & 1.46 & 14.20 & $<.0001$ & -3.32 & 1.88 & -1.77 & 0.08 & 2007 \\
\hline
\end{tabular}




\begin{tabular}{|c|c|c|c|c|c|c|c|c|c|}
\hline Subset & $\beta_{1}$ & $\begin{array}{c}\text { Standard } \\
\text { Error }\end{array}$ & $\begin{array}{c}t- \\
\text { statistic }\end{array}$ & $p$-value & $\boldsymbol{\beta}_{2}$ & $\begin{array}{c}\text { Standard } \\
\text { Error }\end{array}$ & $\begin{array}{c}t- \\
\text { statistic }\end{array}$ & $p$-value & $\begin{array}{c}\text { Year } \beta_{1} \& \\
\beta_{2} \text { Applied } \\
\text { to Metric } \\
\text { Value } \\
\end{array}$ \\
\hline \multicolumn{10}{|c|}{ Operating Cash Flow } \\
\hline 1 & 31.69 & 2.22 & 14.29 & $<.0001$ & 11.65 & 4.49 & 2.59 & 0.01 & 1999 \\
\hline 2 & 37.09 & 2.13 & 17.41 & $<.0001$ & 17.11 & 4.27 & 4.01 & $<.0001$ & 2000 \\
\hline 3 & 40.96 & 2.02 & 20.23 & $<.0001$ & 17.39 & 4.04 & 4.30 & $<.0001$ & 2001 \\
\hline 4 & 38.22 & 1.92 & 19.87 & $<.0001$ & 17.64 & 3.85 & 4.58 & $<.0001$ & 2002 \\
\hline 5 & 37.18 & 1.86 & 20.03 & $<.0001$ & 15.66 & 3.73 & 4.20 & $<.0001$ & 2003 \\
\hline 6 & 38.36 & 1.79 & 21.48 & $<.0001$ & 16.08 & 3.59 & 4.48 & $<.0001$ & 2004 \\
\hline 7 & 37.06 & 1.73 & 21.44 & $<.0001$ & 14.33 & 3.47 & 4.12 & $<.0001$ & 2005 \\
\hline 8 & 36.27 & 1.67 & 21.67 & $<.0001$ & 12.37 & 3.37 & 3.67 & 0.00 & 2006 \\
\hline 9 & 36.13 & 1.62 & 22.25 & $<.0001$ & 12.21 & 3.26 & 3.74 & 0.00 & 2007 \\
\hline \multicolumn{10}{|c|}{ Accruals } \\
\hline 1 & -14.09 & 2.24 & -6.28 & $<.0001$ & -112.66 & 8.01 & -14.06 & $<.0001$ & 1999 \\
\hline 2 & -12.45 & 2.17 & -5.73 & $<.0001$ & -118.00 & 7.75 & -15.22 & $<.0001$ & 2000 \\
\hline 3 & -10.23 & 2.08 & -4.91 & $<.0001$ & -125.69 & 7.39 & -17.01 & $<.0001$ & 2001 \\
\hline 4 & -11.73 & 2.01 & -5.84 & $<.0001$ & -112.16 & 6.99 & -16.06 & $<.0001$ & 2002 \\
\hline 5 & -11.37 & 1.96 & -5.79 & $<.0001$ & -111.57 & 6.80 & -16.42 & $<.0001$ & 2003 \\
\hline 6 & -10.38 & 1.91 & -5.45 & $<.0001$ & -112.50 & 6.61 & -17.03 & $<.0001$ & 2004 \\
\hline 7 & -9.06 & 1.86 & -4.88 & $<.0001$ & -112.53 & 6.43 & -17.49 & $<.0001$ & 2005 \\
\hline 8 & -8.97 & 1.81 & -4.96 & $<.0001$ & -115.58 & 6.28 & -18.41 & $<.0001$ & 2006 \\
\hline 9 & -8.40 & 1.76 & -4.76 & $<.0001$ & -114.66 & 6.11 & -18.77 & $<.0001$ & 2007 \\
\hline \multicolumn{10}{|c|}{ ROA Variability } \\
\hline 1 & -43.85 & 7.11 & -6.17 & $<.0001$ & 25.23 & 5.25 & 4.80 & $<.0001$ & 1999 \\
\hline 2 & -53.72 & 6.71 & -8.00 & $<.0001$ & 31.90 & 4.96 & 6.43 & $<.0001$ & 2000 \\
\hline 3 & -61.02 & 6.22 & -9.80 & $<.0001$ & 33.53 & 4.57 & 7.33 & $<.0001$ & 2001 \\
\hline 4 & -50.82 & 5.77 & -8.81 & $<.0001$ & 28.89 & 4.24 & 6.81 & $<.0001$ & 2002 \\
\hline 5 & -51.17 & 5.49 & -9.33 & $<.0001$ & 29.62 & 4.02 & 7.36 & $<.0001$ & 2003 \\
\hline 6 & -52.42 & 5.01 & -10.46 & $<.0001$ & 29.81 & 3.64 & 8.19 & $<.0001$ & 2004 \\
\hline 7 & -49.17 & 4.72 & -10.42 & $<.0001$ & 28.62 & 3.42 & 8.37 & $<.0001$ & 2005 \\
\hline 8 & -47.74 & 4.53 & -10.53 & $<.0001$ & 27.92 & 3.29 & 8.48 & $<.0001$ & 2006 \\
\hline 9 & -47.66 & 4.36 & -10.93 & $<.0001$ & 27.90 & 3.17 & 8.81 & $<.0001$ & 2007 \\
\hline \multicolumn{10}{|c|}{ Sales Growth Variability } \\
\hline 1 & -1.25 & 0.33 & -3.84 & 0.00 & 0.02 & 0.01 & 2.89 & 0.00 & 1999 \\
\hline 2 & -1.35 & 0.31 & -4.34 & $<.0001$ & 0.03 & 0.01 & 3.21 & 0.00 & 2000 \\
\hline 3 & -1.85 & 0.29 & -6.30 & $<.0001$ & 0.04 & 0.01 & 4.84 & $<.0001$ & 2001 \\
\hline 4 & -1.47 & 0.28 & -5.32 & $<.0001$ & 0.03 & 0.01 & 3.92 & $<.0001$ & 2002 \\
\hline 5 & -1.46 & 0.26 & -5.52 & $<.0001$ & 0.03 & 0.01 & 3.97 & $<.0001$ & 2003 \\
\hline 6 & -1.54 & 0.24 & -6.28 & $<.0001$ & 0.03 & 0.01 & 4.48 & $<.0001$ & 2004 \\
\hline 7 & -1.35 & 0.23 & -5.86 & $<.0001$ & 0.02 & 0.01 & 4.04 & $<.0001$ & 2005 \\
\hline 8 & -1.45 & 0.23 & -6.44 & $<.0001$ & 0.03 & 0.01 & 4.55 & $<.0001$ & 2006 \\
\hline 9 & -1.44 & 0.22 & -6.57 & $<.0001$ & 0.03 & 0.01 & 4.67 & $<.0001$ & 2007 \\
\hline \multicolumn{10}{|c|}{ Asset Turnover (ATO) } \\
\hline 1 & 0.74 & 0.38 & 1.94 & 0.05 & -0.77 & 0.16 & -4.97 & $<.0001$ & 1999 \\
\hline 2 & 0.72 & 0.37 & 1.96 & 0.05 & -0.71 & 0.15 & -4.70 & $<.0001$ & 2000 \\
\hline 3 & 1.95 & 0.36 & 5.50 & $<.0001$ & -1.04 & 0.15 & -7.11 & $<.0001$ & 2001 \\
\hline 4 & 1.41 & 0.34 & 4.11 & $<.0001$ & -0.89 & 0.14 & -6.32 & $<.0001$ & 2002 \\
\hline 5 & 1.68 & 0.34 & 5.01 & $<.0001$ & -0.97 & 0.14 & -7.00 & $<.0001$ & 2003 \\
\hline 6 & 2.02 & 0.33 & 6.19 & $<.0001$ & -1.04 & 0.13 & -7.69 & $<.0001$ & 2004 \\
\hline 7 & 2.16 & 0.32 & 6.80 & $<.0001$ & -1.06 & 0.13 & -8.08 & $<.0001$ & 2005 \\
\hline 8 & 2.31 & 0.31 & 7.47 & $<.0001$ & -1.10 & 0.13 & -8.63 & $<.0001$ & 2006 \\
\hline 9 & 2.25 & 0.30 & 7.48 & $<.0001$ & -1.11 & 0.12 & -8.96 & $<.0001$ & 2007 \\
\hline
\end{tabular}




\begin{tabular}{|c|c|c|c|c|c|c|c|c|c|}
\hline Subset & $\boldsymbol{\beta}_{1}$ & $\begin{array}{c}\text { Standard } \\
\text { Error }\end{array}$ & $\begin{array}{c}t- \\
\text { statistic }\end{array}$ & $p$-value & $\boldsymbol{\beta}_{2}$ & $\begin{array}{c}\text { Standard } \\
\text { Error }\end{array}$ & $\begin{array}{c}t- \\
\text { statistic }\end{array}$ & $p$-value & $\begin{array}{c}\text { Year } \beta_{1} \& \\
\beta_{2} \text { Applied } \\
\text { to Metric } \\
\text { Value } \\
\end{array}$ \\
\hline \multicolumn{10}{|c|}{ Change in ATO } \\
\hline 1 & -11.34 & 5.65 & -2.01 & 0.04 & -253.80 & 27.90 & -9.10 & $<.0001$ & 1999 \\
\hline 2 & -8.85 & 5.57 & -1.59 & 0.11 & -277.45 & 27.58 & -10.06 & $<.0001$ & 2000 \\
\hline 3 & -10.32 & 5.44 & -1.90 & 0.06 & -288.55 & 27.00 & -10.69 & $<.0001$ & 2001 \\
\hline 4 & -9.54 & 5.37 & -1.78 & 0.08 & -289.26 & 26.64 & -10.86 & $<.0001$ & 2002 \\
\hline 5 & -9.41 & 5.34 & -1.76 & 0.08 & -299.07 & 26.50 & -11.29 & $<.0001$ & 2003 \\
\hline 6 & -9.99 & 5.24 & -1.91 & 0.06 & -306.78 & 26.05 & -11.77 & $<.0001$ & 2004 \\
\hline 7 & -8.43 & 5.17 & -1.63 & 0.10 & -307.09 & 25.71 & -11.95 & $<.0001$ & 2005 \\
\hline 8 & -8.96 & 5.10 & -1.76 & 0.08 & -315.11 & 25.35 & -12.43 & $<.0001$ & 2006 \\
\hline 9 & -9.50 & 5.03 & -1.89 & 0.06 & -321.75 & 25.02 & -12.86 & $<.0001$ & 2007 \\
\hline \multicolumn{10}{|c|}{ Leverage } \\
\hline 1 & -0.79 & 0.49 & -1.62 & 0.10 & 0.10 & 0.07 & 1.31 & 0.19 & 1999 \\
\hline 2 & -0.19 & 0.47 & -0.42 & 0.68 & 0.00 & 0.07 & 0.06 & 0.95 & 2000 \\
\hline 3 & 0.67 & 0.45 & 1.49 & 0.14 & -0.12 & 0.07 & -1.81 & 0.07 & 2001 \\
\hline 4 & 0.15 & 0.43 & 0.36 & 0.72 & -0.06 & 0.06 & -0.98 & 0.33 & 2002 \\
\hline 5 & 0.37 & 0.42 & 0.88 & 0.38 & -0.09 & 0.06 & -1.48 & 0.14 & 2003 \\
\hline 6 & 0.76 & 0.40 & 1.88 & 0.06 & -0.13 & 0.06 & -2.15 & 0.03 & 2004 \\
\hline 7 & 0.73 & 0.39 & 1.88 & 0.06 & -0.12 & 0.06 & -2.07 & 0.04 & 2005 \\
\hline 8 & 0.92 & 0.38 & 2.41 & 0.02 & -0.13 & 0.06 & -2.34 & 0.02 & 2006 \\
\hline 9 & 0.85 & 0.37 & 2.28 & 0.02 & -0.14 & 0.06 & -2.45 & 0.01 & 2007 \\
\hline \multicolumn{10}{|c|}{ Liquidity } \\
\hline 1 & 7.51 & 1.27 & 5.92 & $<.0001$ & -19.69 & 3.67 & -5.37 & $<.0001$ & 1999 \\
\hline 2 & 6.37 & 1.22 & 5.21 & $<.0001$ & -21.36 & 3.53 & -6.04 & $<.0001$ & 2000 \\
\hline 3 & 4.85 & 1.18 & 4.12 & $<.0001$ & -25.52 & 3.37 & -7.58 & $<.0001$ & 2001 \\
\hline 4 & 5.70 & 1.14 & 5.01 & $<.0001$ & -22.00 & 3.21 & -6.86 & $<.0001$ & 2002 \\
\hline 5 & 6.50 & 1.11 & 5.84 & $<.0001$ & -25.33 & 3.10 & -8.17 & $<.0001$ & 2003 \\
\hline 6 & 6.04 & 1.08 & 5.58 & $<.0001$ & -27.28 & 2.97 & -9.17 & $<.0001$ & 2004 \\
\hline 7 & 6.32 & 1.06 & 5.96 & $<.0001$ & -29.37 & 2.88 & -10.19 & $<.0001$ & 2005 \\
\hline 8 & 6.45 & 1.03 & 6.23 & $<.0001$ & -30.56 & 2.80 & -10.93 & $<.0001$ & 2006 \\
\hline 9 & 6.16 & 1.01 & 6.10 & $<.0001$ & -29.82 & 2.71 & -10.99 & $<.0001$ & 2007 \\
\hline \multicolumn{10}{|c|}{ Change in Shares } \\
\hline 1 & -5.46 & 1.52 & -3.60 & 0.00 & -0.67 & 1.04 & -0.64 & 0.52 & 1999 \\
\hline 2 & -5.37 & 1.46 & -3.69 & 0.00 & -0.73 & 1.01 & -0.72 & 0.47 & 2000 \\
\hline 3 & -8.38 & 1.40 & -5.98 & $<.0001$ & 0.40 & 0.96 & 0.42 & 0.68 & 2001 \\
\hline 4 & -8.23 & 1.35 & -6.08 & $<.0001$ & 0.36 & 0.93 & 0.38 & 0.70 & 2002 \\
\hline 5 & -7.98 & 1.32 & -6.02 & $<.0001$ & 0.21 & 0.91 & 0.22 & 0.82 & 2003 \\
\hline 6 & -8.16 & 1.28 & -6.37 & $<.0001$ & 0.26 & 0.89 & 0.29 & 0.77 & 2004 \\
\hline 7 & -7.96 & 1.25 & -6.37 & $<.0001$ & 0.23 & 0.87 & 0.26 & 0.79 & 2005 \\
\hline 8 & -8.17 & 1.22 & -6.71 & $<.0001$ & 0.46 & 0.85 & 0.54 & 0.59 & 2006 \\
\hline 9 & -7.96 & 1.18 & -6.72 & $<.0001$ & 0.40 & 0.83 & 0.48 & 0.63 & 2007 \\
\hline \multicolumn{10}{|c|}{ Change in Total Equity } \\
\hline 1 & 0.35 & 0.71 & 0.50 & 0.62 & -0.73 & 0.19 & -3.83 & 0.00 & 1999 \\
\hline 2 & 0.52 & 0.68 & 0.76 & 0.45 & -0.79 & 0.18 & -4.34 & $<.0001$ & 2000 \\
\hline 3 & 0.71 & 0.65 & 1.09 & 0.28 & -0.97 & 0.17 & -5.55 & $<.0001$ & 2001 \\
\hline 4 & 0.84 & 0.63 & 1.34 & 0.18 & -0.95 & 0.17 & -5.68 & $<.0001$ & 2002 \\
\hline 5 & 0.85 & 0.61 & 1.40 & 0.16 & -0.94 & 0.16 & -5.74 & $<.0001$ & 2003 \\
\hline 6 & 1.32 & 0.59 & 2.25 & 0.02 & -1.07 & 0.16 & -6.77 & $<.0001$ & 2004 \\
\hline 7 & 1.43 & 0.57 & 2.51 & 0.01 & -1.08 & 0.15 & -7.01 & $<.0001$ & 2005 \\
\hline 8 & 1.36 & 0.55 & 2.46 & 0.01 & -1.07 & 0.15 & -7.16 & $<.0001$ & 2006 \\
\hline 9 & 1.84 & 0.54 & 3.43 & 0.00 & -1.18 & 0.15 & -8.12 & $<.0001$ & 2007 \\
\hline
\end{tabular}

